\title{
Determination of trace amounts of selenium in natural spring waters and tea samples by catalytic kinetic spectrophotometry
}

\author{
Ramazan Gürkan ${ }^{1+(i)}$, Nevalnur Zeynep Gürkan²(i)
}

1 University of Cumhuriyet, Faculty of Science, Department of Chemistry, Sivas, Turkey

2 Near East University, Faculty of Medicine, Near East Blvd., Nicosia, Cyprus

+Corresponding author: Ramazan Gürkan, Phone: +90 (346) 219 2136, email address: rgurkan@cumhuriyet.edu.tr

\section{ARTICLE INFO}

Article history:

Received: March 6, 2019

Accepted: July 26, 2019

Published: October 1, 2019

\section{Keywords:}

1. inorganic selenium

2. phosphomolybdic acid

3. hypophosphite

4. catalytic kinetic spectrophotometry

5. natural spring water

6. tea samples
ABSTRACT: In this work, a new kinetic method is described for the determination of trace Se(IV) in natural spring waters and commercial tea samples. The method is based on the activation of $\mathrm{Se}(\mathrm{IV})$ onto the indicator reaction in acidic medium. The reaction was monitored using a fixed time approach of $20 \mathrm{~min}$ at $680 \mathrm{~nm}$. The variables affecting the reaction rate were evaluated and optimized. The method allows the determination of Se(IV) in the range of $0.0125-1.0 \mathrm{mg} \mathrm{L}^{-1}$ with a detection limit of $3.6 \mu \mathrm{g} \mathrm{L}^{-1}$. The precision was in range of $0.63-3.15 \%$ (as RSD \%) with a higher recovery than $98.6 \%$. The method has been found to be selective against matrix effect. The method was applied to the speciation analysis of inorganic Se species present in the selected samples. The method was statistically validated by analysis of two certified samples and comparing the obtained results to those of HG-AAS analysis. Also, the total Se levels of the samples were determined by using both methods after conversion of Se(VI) into $\mathrm{Se}(\mathrm{IV})$ in ultrasonic bath in acidic medium for $30 \mathrm{~min}$ at $85-90$ ${ }^{\circ} \mathrm{C}$. The results were in good agreement with those of HG-AAS. The $\operatorname{Se}(\mathrm{VI})$ level of the samples was calculated from the difference between amounts of total Se and Se(IV).
$-1.0 \mathrm{~mL}$ of standard $\mathrm{Se}(\mathrm{IV})$ solution $-0.125-10.0 \mu \mathrm{g} \mathrm{mL}$ range or aliquot of pretreated samples solutions -Addition of reactants of $\mathrm{H}_{2} \mathrm{SO}_{4}, \mathrm{H}_{2} \mathrm{PO}_{2}^{-}, \mathrm{PMA}$ and $\mathrm{Hg}^{2+}$

-Preheating in thermostatic bath $\left(70^{\circ} \mathrm{C}, 20 \mathrm{~min}\right)$

-Cooling down to room temperature

-Absorbance against blank at $680 \mathrm{~nm}$

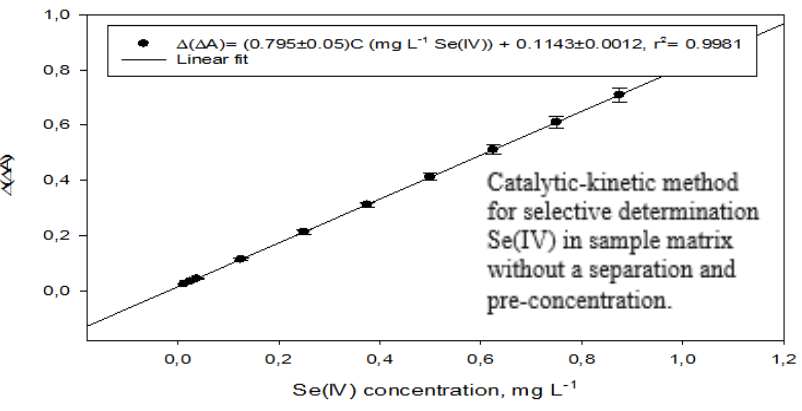

\section{Introduction}

Selenium is an essential trace element with only a small difference between toxic and essential levels. It has been reported that selenium has an anticancer effect, protecting the human body from free radicals and preventing heavy metal toxic effects $^{1}$, but it is also a potential toxicant ${ }^{2}$. Selenium concentration in fresh waters is usually around $20 \mu \mathrm{g} \mathrm{L}^{-1}$. The selenium content of surface waters is greatly influenced by $\mathrm{pH}$, being high in acidic $(\mathrm{pH}<3.0)$ and in alkaline waters $(\mathrm{pH}>7.5)$. Traces of selenium ranging from 0.01 to $10 \mu \mathrm{g} \mathrm{L}^{-1}$ are commonly found in community drinking water.
The guideline level of selenium in drinking water set by the World Health Organization (WHO) was $10 \mu \mathrm{g} \mathrm{L}^{-1}{ }^{3}$. As bioavailability and absorption strongly depend on chemical form in which the element is present, rapid, accurate and precise analytical methodologies for the qualitative and quantitative speciation analysis of selenium in foodstuffs are now becoming more and more necessary ${ }^{4}$. In addition to food, beverages may act as another important potential ingestion way to elements in our daily life ${ }^{5}$. As a popular nonalcoholic and healthy beverage, tea is massively consumed in the world ${ }^{6}$. The regular consumption of tea may contribute to the daily 
dietary requirements of several essential elements. Considering the enormous consumption of tea and the investigation focusing on selenium, there is great importance to study inorganic selenium speciation in tea samples as well as in natural waters ${ }^{7}$.

There are many analytical techniques with their self-advantages and disadvantages, such as capillary electrophoresis online coupled with hydride generation-atomic fluorescence spectrometry (CE/HG AFS $)^{2}$, inductively coupled plasma mass spectrometry (ICP MS) after a separation and preconcentration procedure ${ }^{4,7}$, spectrophotometry with and without preconcentration $^{8,9}$, graphite furnace atomic absorption spectrometric (GF AAS) after preconcentration with coprecipitation $^{10}$, electrothermal atomic absorption spectrometry (ET AAS) ${ }^{11}$, inductively coupled plasma optical emission spectrometry with hydride generation (HG ICP OES) $)^{12}$, atomic absorption spectrometry with hydride generation (HG AAS) ${ }^{13}$, and high performance liquid chromatography with UV detection (HPLC) $)^{14-17}$ in literature for speciation analysis of inorganic selenium species.

In routine analysis, the spectrophotometric method is a versatile and cost-effective analytical tool that is easy to use, simple and requires no expert user in this area for underdeveloped and developing countries. However, the abovementioned methods are time-consuming or less sensitive. Catalytic kinetic methods are noteworthy due to their significant advantages in determining many organic and inorganic components at trace levels without the need for prior separation and enrichment step with the choice of a good indicator, catalyst, inhibitor and activator.

Different catalytic kinetic methods have been reported for the determination of inorganic selenium species like $\mathrm{Se}(\mathrm{IV}), \mathrm{Se}(\mathrm{VI})$ and total selenium in waters ${ }^{18-24}$, including micellar sensitized kinetic quantification of low levels of bisphenol A in foodstuffs by spectrophotometry ${ }^{25}$. Significant number of methods for the determination of selenium in real samples have been based on the catalytic effect of $\mathrm{Se}(\mathrm{IV})$ on the reduction of absorbing chromogenic or fluorogenic dyes in visible region, $380-800 \mathrm{~nm}$, such as Toluidine blue $^{26}$, Methylene blue ${ }^{27}$, Gallocyanin ${ }^{28}$, Semicarbazite $^{29}$, and Ponceau $\mathrm{S}^{30}$. Some of these methods have high selection limits or suffer from many interfering species such as $\mathrm{Te}(\mathrm{IV})$ and $\mathrm{As}(\mathrm{V})$, have time-consuming and laborious processes, and at the same time these methods are unstable. There are a limited number of catalytic kinetic methods that allow the determination of $\mathrm{Se}(\mathrm{IV}), \mathrm{Se}(\mathrm{VI})$ and total selenium in water samples ${ }^{31}$. Therefore, there is still a need to develop more sensitive and selective catalytic kinetic spectrophotometric methods for the determination and speciation of selenium in real matrix samples such as natural hot springs and tea samples.

In the present study, $\mathrm{Se}(\mathrm{IV})$ was used as an activator to increase the sensitivity and stability of the indicator system, $\mathrm{Hg}(\mathrm{II})-\mathrm{PMA}-\mathrm{NaH}_{2} \mathrm{PO}_{2}-$ $\mathrm{H}_{2} \mathrm{SO}_{4}$. The variables affecting the reaction rate were evaluated in detail and optimized to give the best calibration sensitivity. The developed activation-controlled kinetics system has been successfully applied to speciation analysis of the inorganic selenium species present in natural spring water and tea samples. The proposed kinetic method is sufficiently sensitive, selective, very simple and practical to use. The existing kinetic method, without any pre-separation and enrichment, is as accurate and reliable as the sensitive and element selective HG AAS, which is commonly used for selenium analysis in real samples.

\section{Materials and methods}

\subsection{Instrumentation}

In the present study, a spectrophotometer equipped with a $1 \mathrm{~cm}$ light path quartz cell (Shimadzu model UV-Visible 1601 PC, Kyoto, Japan) was used for absorbance measurements at $680 \mathrm{~nm}$. A thermostatic water bath was used to control the reaction temperature with accuracy of $\pm 0.5{ }^{\circ} \mathrm{C}$. A stopwatch was used to record the reaction time. Shortly before the start of the indicator reaction with and without the activator, all the solutions were preheated to a temperature of $70{ }^{\circ} \mathrm{C}$. A Sonicor model SC-121TH ultrasonic probe with total volume of $4 \mathrm{~L}$ was used for ultrasonic dissolution (optimal conditions, $35 \mathrm{kHz}$, $220 \mathrm{~V}$, for $15 \mathrm{~min}$ at $65^{\circ} \mathrm{C}$ ). In addition, HG AAS (in terms of total $\mathrm{Se}$ analysis) was also used to check the accuracy of the method. For comparative purposes, the hydride for Se analysis was run with an atomic absorption spectrometer (HG AAS, Shimadzu AAS-6300, HVG-13 channels) forming under the following operating conditions: $4.0(\mathrm{w} / \mathrm{v})$ $\mathrm{NaBH}_{4}$, 6-8 mol L-1 $\mathrm{HCl}$, carrier argon gas at a pressure of $0.32 \mathrm{MPa}$ at a flow rate of $70 \mathrm{~mL} \mathrm{~min}^{-1}$, 
air at a flow rate of $7.0 \mathrm{~L} \mathrm{~min}^{-1}$ for fuel/burner acetylene at a flow rate of $15 \mathrm{~L} \mathrm{~min}^{-1}, 0.2 \mathrm{~nm}$ bandwidth, $194.0 \mathrm{~nm}$ wavelength and $10 \mathrm{~mA}$ lamp current.

\subsection{Chemicals and solutions}

All chemicals used were in analytical reagent purity. $1000 \mathrm{mg} \mathrm{L}^{-1} \mathrm{Se}(\mathrm{IV})$ and $\mathrm{Se}(\mathrm{VI})$ solutions were prepared by dissolving the appropriate amounts of solid $\mathrm{Na}_{2} \mathrm{SeO}_{3}$ and $\mathrm{Na}_{2} \mathrm{SeO}_{4}$ in doubly distilled water and completing with water to the line. $100 \mathrm{~mL}$ of $1.5 \mathrm{~mol} \mathrm{~L}^{-1} \mathrm{H}_{2} \mathrm{SO}_{4}$ solution was prepared by diluting the concentrated solution with water. $100 \mathrm{~mL}$ of $0.5(\mathrm{w} / \mathrm{v})$ PMA solutions was also prepared by dissolving $0.5 \mathrm{~g}$ of solid PMA in diluted $\mathrm{NaOH}$ and diluting with water. $100 \mathrm{~mL}$ of $0.5 \mathrm{~mol} \mathrm{~L}^{-1}$ hypophosphite solution was prepared by dissolving suitable amounts of solid $\mathrm{NaH}_{2} \mathrm{PO}_{2}$ in water, homogenizing thoroughly with water and soaking in water. $100 \mathrm{~mL}$ of $0.01 \mathrm{~mol} \mathrm{~L}^{-1} \mathrm{Hg}$ (II) ion solution was prepared by dissolving a known amount of solid $\mathrm{Hg}\left(\mathrm{NO}_{3}\right)_{2}$ salt in analytical purity in water and diluting with water. The other reagents $\left(\mathrm{HNO}_{3}, \mathrm{H}_{2} \mathrm{O}_{2}, \mathrm{HCl}\right.$ and $1.5 \%(\mathrm{w} / \mathrm{v}) \mathrm{NaBH}_{4}$ in $0.2 \%$ $(\mathrm{w} / \mathrm{v}) \mathrm{NaOH})$ used in dissolution of the samples, interference studies and selenium analysis steps by $\mathrm{Hg}$ AAS, were used by either direct or preparing solutions at known concentrations.

\subsection{Preparation of samples for analysis}

Natural cold- and hot-spring water samples were directly collected from the cold and hot spring (Kalin Town, Sivas, Turkey) and stored in a cool, dark place to protect them from heat and light. Water samples were acidified using dilute $\mathrm{HNO}_{3}$ to prevent metal ions from adsorbing on the walls of the measurement containers. Samples were passed through a $0.45 \mu \mathrm{m}$ pore size membrane filter to remove suspended solids prior to analysis. To determine the total selenium, samples were submitted to analysis under optimum reagent conditions, without any other pretreatment, except for prereduction with $\mathrm{HCl}$. Where necessary, known volumes of masking reagents such as thiourea and $\mathrm{NH}_{4} \mathrm{~F}$ were added to the solution medium prior to analysis to control possible interference resulted from $\mathrm{Te}(\mathrm{IV}), \mathrm{Cu}(\mathrm{II}), \mathrm{Bi}(\mathrm{III})$ and $\mathrm{Sn}(\mathrm{IV})$ ions. At least, one blank solution for each sample was also analyzed to evaluate metal contamination with the reagents used.
Initially, the certified tea sample (about 0.1$0.2 \mathrm{~g}$ ) was subjected to analysis for different sonication times (5-30 $\mathrm{min})$, temperature (25$\left.80{ }^{\circ} \mathrm{C}\right)$ and $\mathrm{H}_{2} \mathrm{SO}_{4}$ concentration $\left(0.2-5 \mathrm{~mol} \mathrm{~L}^{-1}\right)$ under $35 \mathrm{kHz}$ ultrasonic power for the optimization of the ultrasonically assisted dissolution process. The certified value of sample was considered as base to assess the effectiveness of the procedure. Optimal values were found to be an acid concentration of $3.5 \mathrm{~mol} \mathrm{\textrm {L } ^ { - 1 }}$, sonication temperature of $65^{\circ} \mathrm{C}$ and sonication time of $15 \mathrm{~min}$ after each optimization step. Real tea samples were solubilized in these conditions, converted to hydride, $\mathrm{H}_{2} \mathrm{Se}$ after reduction with $1.5 \%(\mathrm{w} / \mathrm{v})$ $\mathrm{NaBH}_{4}$ in acidic medium $\left(4.0 \mathrm{~mol} \mathrm{~L}^{-1} \mathrm{HCl}\right)$ and detected with HG-AAS. Approximately $0.1 \mathrm{~g}$ of tea samples was taken in PTFE dissolution vessels for five repetitive analyzes, and each was mixed with $5 \mathrm{~mL}$ of concentrated acid and/or acid mixture $\left(\mathrm{H}_{2} \mathrm{SO}_{4}\right.$ or $\left.\mathrm{H}_{2} \mathrm{SO}_{4}-\mathrm{HNO}_{3}-\mathrm{H}_{2} \mathrm{O}_{2}, 2: 2: 1(\mathrm{v} / \mathrm{v})\right)$. The flasks were covered with a watch glass, and then dissolved at $60-80{ }^{\circ} \mathrm{C}$ for $3-4 \mathrm{~h}$. The acid and/or acid mixtures were intermittently added until the color of the solution became transparent, and the heating was continued. The excess acid was evaporated until a semi-dried mass remained; 2.0 $\mathrm{mL}$ of $0.2 \mathrm{~mol} \mathrm{~L}^{-1} \mathrm{HNO}_{3}$ was added to this after cooling and centrifuged for $10 \mathrm{~min}$ at $3500 \mathrm{rpm}$. Final volume was completed to a volume of 5.0$10 \mathrm{~mL}$ using $0.5 \mathrm{~mol} \mathrm{~L}^{-1} \mathrm{HNO}_{3}$, and the known volumes of sample solution were analyzed by kinetic method. For the tea samples below the detection limit, the standard addition-based calibration curve approach was used when necessary, and the total selenium level of the sample was determined from difference after prereduction. The blank samples were analyzed in a similar way.

\subsection{The catalytic kinetic procedure}

A suitable volume $(1.0 \mathrm{~mL})$ of standard $\mathrm{Se}(\mathrm{IV})$ or sample solution in linearity range of 0.125 $10.0 \mu \mathrm{g} \mathrm{mL}^{-1}$ was transferred to a centrifugation tube of $10 \mathrm{~mL}$, and then $0.5 \mathrm{~mL}$ of $1.5 \mathrm{~mol} \mathrm{~L}^{-1}$ $\mathrm{H}_{2} \mathrm{SO}_{4}, 0.1 \mathrm{~mL}$ of $0.5 \mathrm{~mol} \mathrm{~L}^{-1} \mathrm{H}_{2} \mathrm{PO}_{2}^{-}, 1.5 \mathrm{~mL}$ of $0.5 \%$ (w/v) PMA and $0.75 \mathrm{~mL}$ of $0.01 \mathrm{~mol} \mathrm{~L}^{-1} \mathrm{Hg}^{2+}$ solutions were sequentially added. After that, the volume was completed to $10 \mathrm{~mL}$ with water and incubated at $70 \pm 0.5{ }^{\circ} \mathrm{C}$ for a fixed time of $20 \mathrm{~min}$. The thermostat was left in the equilibrium in the water bath. Finally, the solution was brought to room temperature by holding under the running 
tap. The absorbance of the indicator solution at $680 \mathrm{~nm}$ for analysis of $\mathrm{Se}(\mathrm{IV})$ was measured against water using a 1-cm quartz cell and taken as an analytical signal. In a similar way, under optimal conditions, the absorbance was measured for the noncatalyzed solution without $\mathrm{Se}(\mathrm{IV})$ and the signal $\Delta \mathrm{A}_{\mathrm{C}}$ was taken into account. As a measure of calibration sensitivity, $\Delta(\Delta \mathrm{A}): \quad \Delta \mathrm{A}_{\mathrm{c}}-\Delta \mathrm{A}_{0}$ difference as a net analytical signal was plotted versus $\mathrm{Se}(\mathrm{IV})$ concentration, and a calibration curve was generated. The selenium contents of the samples were determined using this calibration curve.

\section{Results and discussion}

\subsection{Absorption properties}

Phosphomolybdic acid (PMA), a heteropoly acid with three acid ionization constants $\left(\mathrm{pK}_{\mathrm{a} 1,2,3}\right.$ : $2.40,4.32$ and 5.46), is a dye which is commonly used for sensitive detection of low molecular mass compounds such as alkaloids, phenolic species and steroids for visualization of complex biological structures in TLC. PMA $\left(\mathrm{H}_{3} \mathrm{PMo}_{12} \mathrm{O}_{40}, \quad\right.$ FA: $1825.25 \mathrm{~g} \mathrm{moL}^{-1}$ ), also known as dodeca molybdic acid, is a yellowish-green compound, soluble in polar organic solvents such as water and ethanol. Conjugate unsaturated compounds reduce PMA to Mo-blue. Color intensity increases with the number of conjugated double bonds present in the dye molecule ${ }^{32}$. The PMA's implementation principle is based on the fact that many inorganic and organic materials form highly colored blue mixed oxide where the initial Mo(VI) is reduced to Mo(IV). Similar reaction products can be easily monitored by light and electron microscopy and can be measured by spectroscopic techniques, usually at a wavelength of $600-900 \mathrm{~nm}$, depending on the nature of the reducing agent used ${ }^{33,34}$. Different investigators $^{35-41}$ reported different absorption spectra with different wavelengths for maximum absorption for the Mo-blue complex. In the present study, when sodium hypophosphite was used as a reducing agent for PMA, and when $\mathrm{H}_{2} \mathrm{SO}_{4}$ was added, intense blue color appeared. The shape and maximum absorption wavelength of the absorption spectra are changed by changing the concentration of acid in solution in the presence of $\mathrm{Hg}$ (II) and $\mathrm{Se}(\mathrm{IV})$ ions at constant concentrations. A comparison between these spectra showed that the maximum absorbance for a solution containing $0.075 \mathrm{~mol} \mathrm{~L}^{-1} \mathrm{H}_{2} \mathrm{SO}_{4}$ in a final volume of $10 \mathrm{~mL}$ was observed at $680 \mathrm{~nm}$. Increasing $\mathrm{Hg}$ (II) and $\mathrm{Se}(\mathrm{IV})$ concentrations at constant acid concentration also led to an increase in the absorbance at the characteristic absorption wavelength. For this reason, $680 \mathrm{~nm}$ was taken into account as working wavelength for further studies.

\subsection{Indicator reaction}

PMA was used as a redox indicator because of its ability to produce a product such as Mo-blue, which has a characteristic absorption effect on the visible region when reduced. Reduction of PMA in the presence of hypophosphite in acidic medium at room temperature is very slow. However, $\mathrm{Se}(\mathrm{IV})$ at trace levels activates selectively the catalytic effect of $\mathrm{Hg}$ (II) ions in acidic medium at $70{ }^{\circ} \mathrm{C}$. This can be explained by the stable complex formation of $\mathrm{Se}(\mathrm{IV})$ in the catalytic cycle of $\mathrm{Hg}$ (II) ions in the acidic medium. According to Pearson's acid-base theory, $\mathrm{Hg}(\mathrm{II})$, which is soft Lewis acid, will interact with the soft base $\mathrm{Se}(\mathrm{IV})$ to form $\mathrm{Hg}$-Se bond. The rate increase observed in the catalytic behavior of $\mathrm{Hg}(\mathrm{II})$ in the presence of trace $\mathrm{Se}$ (IV) was spectrophotometrically monitored at $680 \mathrm{~nm}$. The catalytic reaction mechanism, based on the expected activation, can be predicted as follows:

$$
\begin{aligned}
& \mathrm{H}_{3} \mathrm{PMo}_{12} \mathrm{O}_{40}+12 \mathrm{H}_{2} \mathrm{O} \quad \rightarrow \quad 27 \mathrm{H}^{+}+\mathrm{PO}_{4}{ }^{3-}+12 \mathrm{MoO}_{4}{ }^{2-}\left(\mathrm{pK}_{\mathrm{a1}, 2,3}: 2.40,4.31\right. \text { and 5.46) } \\
& 2 \mathrm{MoO}_{4}{ }^{2-}+\mathrm{H}_{2} \mathrm{PO}_{2}^{-}+4 \mathrm{H}^{+} \rightarrow \mathrm{Mo}_{2} \mathrm{O}_{5} \times 2 \mathrm{H}_{2} \mathrm{O}+\mathrm{H}_{2} \mathrm{PO}_{3}^{-} \text {(slow, uncatalyzed reaction) Mo-blue } \\
& \text { (i) } 2 \mathrm{Hg}^{2+}+\mathrm{H}_{2} \mathrm{PO}_{2}^{-}+\mathrm{H}_{2} \mathrm{O} \quad \rightarrow \quad \mathrm{Hg}_{2}^{2+}+2 \mathrm{H}^{+}+\mathrm{H}_{2} \mathrm{PO}_{3}^{-} \\
& \text {(ii) } \mathrm{Hg}^{2+}+\mathrm{H}_{2} \mathrm{SeO}_{3} \quad \rightarrow \quad \mathrm{Hg}\left(\mathrm{SeO}_{3} \mathrm{H}\right)^{+}+\mathrm{H}^{+}\left(\mathrm{pK}_{\mathrm{a} 1,2}: 2.46\right. \text { and 7.30) } \\
& \text { (iii) } \mathrm{Hg}\left(\mathrm{SeO}_{3} \mathrm{H}\right)^{+}+\mathrm{H}_{2} \mathrm{SeO}_{3} \rightarrow \mathrm{Hg}\left(\mathrm{SeO}_{3} \mathrm{H}\right)_{2}+\mathrm{H}^{+}, \log \beta_{2}: 7.69 \text { (stable complex formation) } \\
& \text { (iv) } 2 \mathrm{Hg}\left(\mathrm{SeO}_{3} \mathrm{H}\right)_{2}+\mathrm{H}_{2} \mathrm{PO}_{2}^{-}+\mathrm{H}_{2} \mathrm{O} \rightarrow \mathrm{Hg}_{2}{ }^{2+}+2 \mathrm{HSeO}_{3}{ }^{-}+\mathrm{H}_{2} \mathrm{PO}_{3}^{-} \\
& \text {(v) } 2 \mathrm{MoO}_{4}^{2-}+\mathrm{Hg}_{2}^{2+}+6 \mathrm{H}^{+} \rightarrow 2 \mathrm{Hg}^{2+}+\mathrm{Mo}_{2} \mathrm{O}_{5} \times 2 \mathrm{H}_{2} \mathrm{O}+\mathrm{H}_{2} \mathrm{O} \\
& 2 \mathrm{MoO}_{4}{ }^{2-}+\mathrm{H}_{2} \mathrm{PO}_{2}{ }^{-}+4 \mathrm{H}^{+} \rightarrow \mathrm{Mo}_{2} \mathrm{O}_{5} \times 2 \mathrm{H}_{2} \mathrm{O}+\mathrm{H}_{2} \mathrm{PO}_{3}^{-} \\
& \text {(Fast, catalyzed reaction in presence of } \mathrm{Se}(\mathrm{IV}) \text { ) at } 680 \mathrm{~nm} \text {. }
\end{aligned}
$$




\subsection{Optimization of the analytical variables}

The effect of reaction variables (acidity, concentration of reactants, temperature, time, and ionic strength of the medium) on the net reaction rate was extensively evaluated and optimized by monitoring each variable at a certain interval by keeping all other variables constant, based on optimization tool which is also well-known as univariate approach. In fact, in which there is not an interaction between variables, this approach is simpler, easy to use, more reliable, and moreover does not require an expert user (herein, a mathematician or statistician, which can statistically use multivariate models in optimization step) in his/her area to determine whether or not a variable is significant, and to establish relationships between variables as only one variable is used each time to obtain results. The optimum values of the variables for triplicate measurements of selenium at fixed concentration of $0.25 \mathrm{mg} \mathrm{L}^{-1}$ were determined to obtain the minimum detection limit and maximum sensitivity at each determination. The results were represented as error bars showing the mean and standard deviation of each replicate measurement sets in all figures.

\subsubsection{Effect of acidity}

The effect of acidity on the sensitivity, which is a measure of the rate difference between catalytic and noncatalytic reactions, was investigated in the range of $0.1-2.0 \mathrm{~mL}$ of $1.5 \mathrm{~mol} \mathrm{~L}^{-1} \mathrm{H}_{2} \mathrm{SO}_{4}$. The sensitivity, $\Delta(\Delta \mathrm{A})$, for the fixed-time of first 20 min at $70{ }^{\circ} \mathrm{C}$ in Fig. 1 was plotted against the volume of acid by keeping other reagent concentrations constant, and the maximum sensitivity was observed to be $0.5 \mathrm{~mL}$. Sensitivity decreases at lower and higher acid volumes. This high acidity also indicates that the rate of the uncatalyzed reaction is more effective than the catalyzed reaction. At low concentrations, the activation power of $\mathrm{Se}$ (IV) may not be effective enough. As a result, $0.5 \mathrm{~mL}$ of $1.5 \mathrm{~mol} \mathrm{~L}^{-1} \mathrm{H}_{2} \mathrm{SO}_{4}$ concentration was considered to be sufficient for further studies.

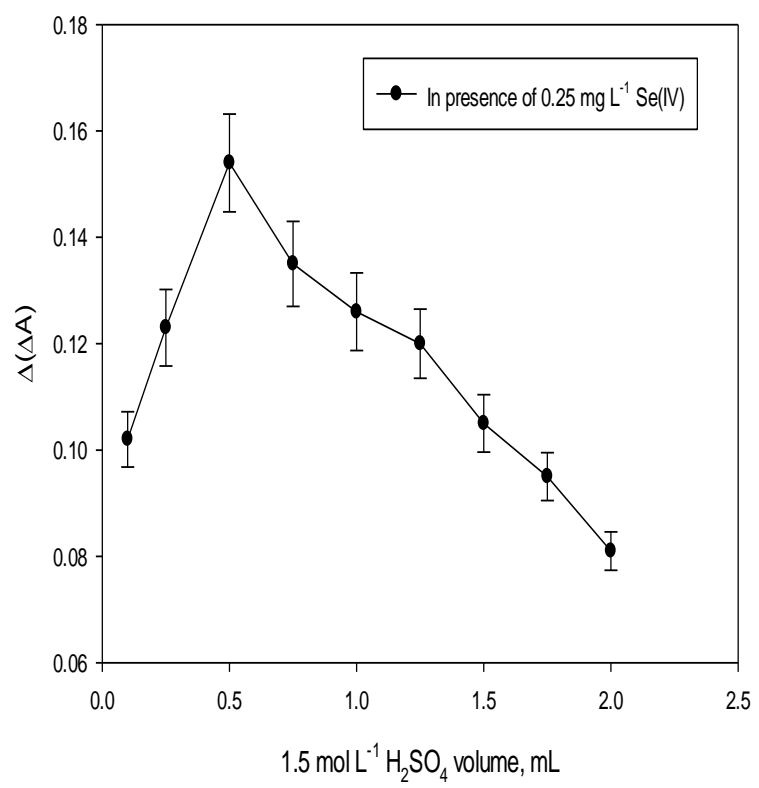

Figure 1. The effect of acidity on sensitivity. Optimal conditions: [Se(IV)]: $250 \mu \mathrm{g} \mathrm{L}^{-1}$, [PMA]: $0.041 \mathrm{~mol} \mathrm{~L}^{-1}$, $\left[\mathrm{H}_{2} \mathrm{PO}_{2}^{-}\right]: 5.0 \times 10^{-3} \mathrm{~mol} \mathrm{~L}^{-1},\left[\mathrm{Hg}^{2+}\right]: 7.5 \times 10^{-4} \mathrm{~mol} \mathrm{~L}^{-1}$, fixed-time: $20 \mathrm{~min}$, temperature: $70^{\circ} \mathrm{C}$ at $680 \mathrm{~nm}$.

\subsubsection{Effect of reducing agent volume}

The effect of the hypophosphite concentration on the sensitivity was investigated using $0.5 \mathrm{~mol} \mathrm{~L}^{-1}$ hypophosphite at constant concentration, by keeping the other reagent concentrations constant at $680 \mathrm{~nm}$ in Fig. 2, and its volume was ranged from 0.025 to $1.25 \mathrm{~mL}$ for 20 $\min$ at $70{ }^{\circ} \mathrm{C}$. The volume of hypophosphite increased for both catalyzed and uncatalyzed reaction in range of $0.025-0.1 \mathrm{~mL}$. At higher volumes, the sensitivity has decreased proportionally as the difference between the rate differences decreases. Therefore, a hypophosphite volume of $0.1 \mathrm{~mL}$ was considered as the optimal value. 


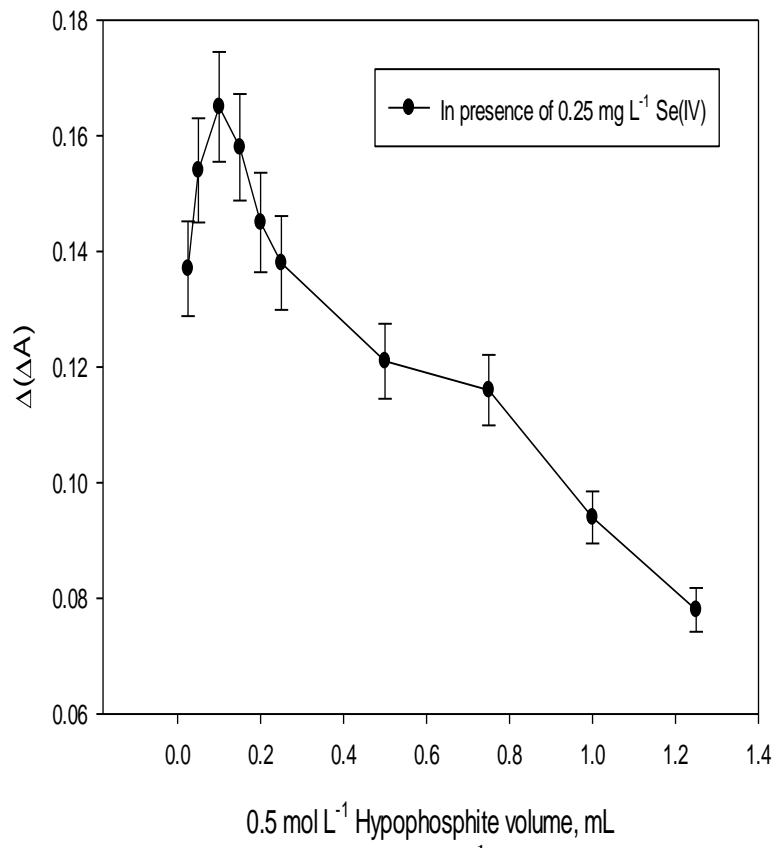

Figure 2. Effect of $0.5 \mathrm{~mol} \mathrm{~L}^{-1}$ hypophosphite volume on sensitivity. Optimal conditions: [Se(IV)]: $250 \mu \mathrm{g} \mathrm{L}^{-1}$, [PMA]: $0.041 \mathrm{~mol} \mathrm{~L}^{-1},\left[\mathrm{H}_{2} \mathrm{SO}_{4}\right]: 0.075 \mathrm{~mol} \mathrm{~L}^{-1},\left[\mathrm{Hg}^{2+}\right]$ : $7.5 \times 10^{-4} \mathrm{~mol} \mathrm{~L}^{-1}$, fixed-time: $20 \mathrm{~min}$, temperature: $70^{\circ} \mathrm{C}$ at $680 \mathrm{~nm}$.

\subsubsection{Effect of PMA volume}

The effect of PMA volume on sensitivity was investigated in the range of $0.25-2.0 \mathrm{~mL}$ of $0.5 \%$ $(\mathrm{w} / \mathrm{v})$ in Fig. 3. The sensitivity for the fixed time of 20 min at $70{ }^{\circ} \mathrm{C}$ was plotted versus its volume, by keeping the other reagent concentrations constant at $680 \mathrm{~nm}$, and the maximum sensitivity was observed to be $1.5 \mathrm{~mL}$. In low volumes, sensitivity has increased up to $1.5 \mathrm{~mL}$, while in higher volumes the slope gradually declines with a decreasing slope. This decrease in sensitivity is due to the fact that the noncatalytic reaction rate is faster than the catalytic reaction. High sensitivity at low volumes can be explained by the fact that the activation power of $\mathrm{Se}(\mathrm{IV})$ is more effective. Therefore, a PMA volume of $1.5 \mathrm{~mL}$ was considered as optimal for further studies.

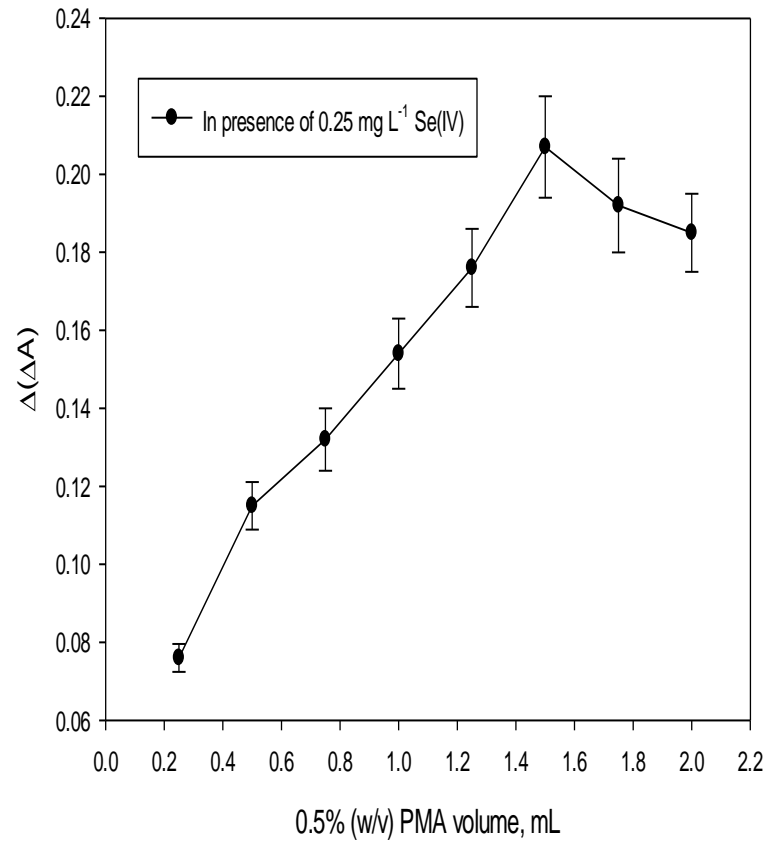

Figure 3. Effect of PMA volume on sensitivity. Optimal conditions: $[\mathrm{Se}(\mathrm{IV})]: \quad 250 \mu \mathrm{g} \quad \mathrm{L}^{-1}, \quad\left[\mathrm{H}_{2} \mathrm{SO}_{4}\right]$ : $0.075 \mathrm{~mol} \mathrm{~L}^{-1},\left[\mathrm{H}_{2} \mathrm{PO}_{2}^{-}\right]: 5.0 \times 10^{-3} \mathrm{~mol} \mathrm{~L}{ }^{-1},\left[\mathrm{Hg}^{2+}\right]$ : $7.5 \times 10^{-4} \mathrm{~mol} \mathrm{~L}^{-1}$, fixed-time: $20 \mathrm{~min}$, temperature: $70{ }^{\circ} \mathrm{C}$ at $680 \mathrm{~nm}$.

\subsubsection{Effect of $H g(I I)$ volume}

The effect of $\mathrm{Hg}$ (II) volume on sensitivity was examined in the range of $0.1-2.0 \mathrm{~mL}$ of $0.01 \mathrm{~mol} \mathrm{~L}^{-1}$. The sensitivity for the fixed time of 20 min at $70{ }^{\circ} \mathrm{C}$ was plotted versus $\mathrm{Hg}$ (II) volume in Fig. 4, by keeping the other reagent concentrations constant at $680 \mathrm{~nm}$, and the maximum sensitivity was observed to be $0.75 \mathrm{~mL}$. Sensitivity increased up to $0.75 \mathrm{~mL}$ at low volumes with increasing slope, declined with a decreasing slope in range of $0.75-1.5 \mathrm{~mL}$, and remained constant in range of 1.5-2.0 mL. This decrease in sensitivity may be due to the fact that the noncatalytic reaction rate is faster than the catalytic reaction. Another explanation is that after the $\mathrm{Hg}$ (II)-complex formed in the presence of Se(IV) is reduced to $\mathrm{Hg}(\mathrm{I})$-complex by hypophosphite, the reduced complex or $\mathrm{Hg}_{2}{ }^{2+}$ ions can be converted to metallic $\mathrm{Hg}$ and $\mathrm{Hg}$ (II) by disproportionation. High sensitivity at low concentrations can be explained by the fact that the activation power of $\mathrm{Se}$ (IV) is more effective. Therefore, an $\mathrm{Hg}$ (II) volume of $0.75 \mathrm{~mL}$ was considered as optimal for further studies. 


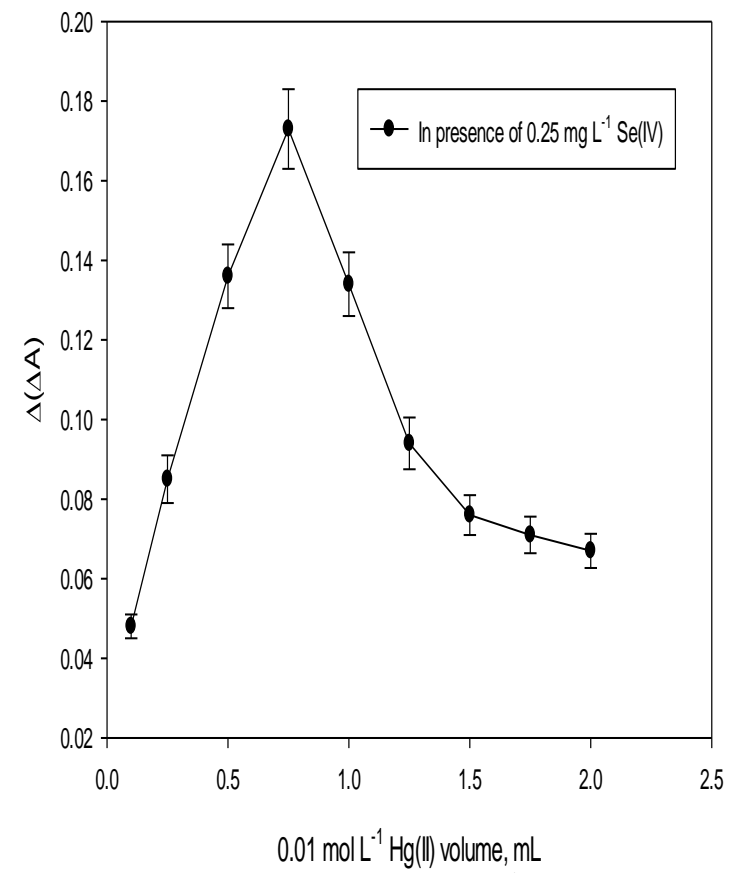

Figure 4. Effect of $0.01 \mathrm{~mol} \mathrm{~L}^{-1} \mathrm{Hg}$ (II) volume on sensitivity. Optimal conditions: [Se(IV)]: $250 \mu \mathrm{g} \mathrm{L}^{-1}, \quad\left[\mathrm{H}_{2} \mathrm{SO}_{4}\right]: 0.075 \mathrm{~mol} \mathrm{~L} \mathrm{~L}^{-1}, \quad$ [PMA]: $0.041 \mathrm{~mol} \mathrm{~L}^{-1},\left[\mathrm{H}_{2} \mathrm{PO}_{2}^{-}\right]: 5.0 \times 10^{-3} \mathrm{~mol} \mathrm{~L}^{-1}$, fixedtime: $20 \mathrm{~min}$, temperature: $70^{\circ} \mathrm{C}$ at $680 \mathrm{~nm}$.

\subsubsection{Effect of temperature on sensitivity}

At optimal conditions, the effect of temperature on the sensitivity was investigated in range of 40$85^{\circ} \mathrm{C}$ in Fig. 5 because no significant difference in sensitivity was observed in room conditions. Both the catalytic and noncatalytic reaction rates increased with increasing temperature in range of $40-70{ }^{\circ} \mathrm{C}$, in which the rate of catalytic reaction was more pronounced. Sensitivity decreased at temperatures higher than $70{ }^{\circ} \mathrm{C}$. This reduction may be due to the fact that the noncatalytic reaction rate is relatively faster. For this reason, a temperature of $70{ }^{\circ} \mathrm{C}$ was considered as optimal for further studies. To check for possible signal fluctuations at this temperature, the analysis was carried out in a water bath, where the temperature was thermostatically controlled with an accuracy of $\pm 0.2^{\circ} \mathrm{C}$.

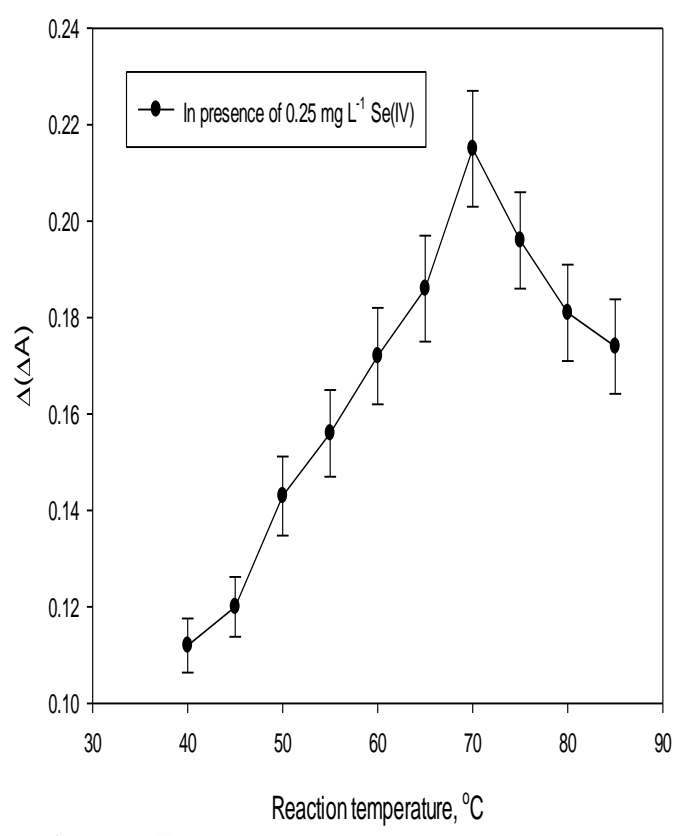

Figure 5. Effect of reaction temperature on sensitivity. Optimal conditions: [Se(IV)]: $250 \mu \mathrm{g} \mathrm{L}^{-1},\left[\mathrm{H}_{2} \mathrm{SO}_{4}\right]: 0.075 \mathrm{~mol} \mathrm{~L} \mathrm{~L}^{-1},[\mathrm{PMA}]$ : $0.041 \mathrm{~mol} \mathrm{~L}^{-1},\left[\mathrm{H}_{2} \mathrm{PO}_{2}^{-}\right]: 5.0 \times 10^{-3} \mathrm{~mol} \mathrm{~L}^{-1}$, $\left[\mathrm{Hg}^{2+}\right]: 7.5 \times 10^{-4} \mathrm{~mol} \mathrm{~L}^{-1}$, fixed-time: $20 \mathrm{~min}$ at $680 \mathrm{~nm}$.

\subsubsection{Effect of reaction time on sensitivity}

Under optimum reagent conditions, the effect of reaction time on sensitivity was studied in time interval of 5-40 $\mathrm{min}$ at $70^{\circ} \mathrm{C}$ in Fig. 6. The catalytic and noncatalytic reaction rates were monitored at $680 \mathrm{~nm}$, and the sensitivity increased with increasing time in 5 min intervals; however, the catalytic reaction rate was more pronounced in this time interval. Sensitivity was decreased at longer times than $20 \mathrm{~min}$. This decrease can be caused by acceleration in the noncatalytic reaction rate, so as to lead to a decrease in the signal difference. So, for more advanced applications, a reaction time of 20 min was considered as optimal. 


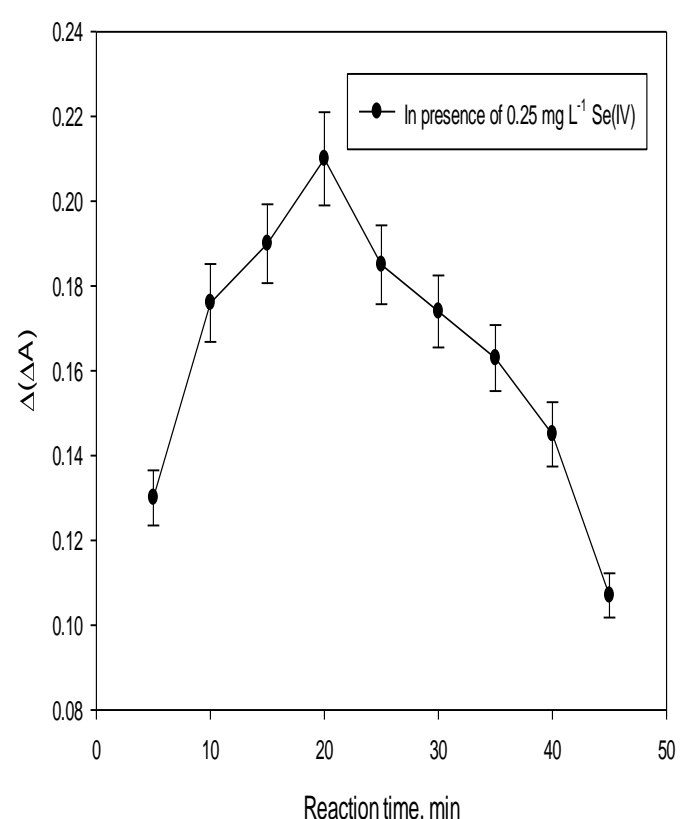

Figure 6. Effect of reaction time on sensitivity. Optimal conditions: [Se(IV)]: $250 \mu \mathrm{g} \mathrm{L}^{-1}$, [PMA]: $0.041 \mathrm{~mol} \mathrm{~L}^{-1},\left[\mathrm{H}_{2} \mathrm{SO}_{4}\right]: 0.075 \mathrm{~mol} \mathrm{~L}^{-1},\left[\mathrm{H}_{2} \mathrm{PO}_{2}{ }^{-}\right]$: $5.0 \times 10^{-3} \mathrm{~mol} \mathrm{~L} \mathrm{~L}^{-1},\left[\mathrm{Hg}^{2+}\right]: \quad 7.5 \times 10^{-4} \mathrm{~mol} \mathrm{~L}^{-1}$, temperature: $70{ }^{\circ} \mathrm{C}$ at $680 \mathrm{~nm}$.

\subsubsection{Effect of inert salt concentration as a function of ionic strength on sensitivity}

The effect of ionic strength on the catalyzed and uncatalyzed reaction was investigated in the volume range of $0.1-1.0 \mathrm{~mL}$ of $0.5 \mathrm{~mol} \mathrm{~L}^{-1} \mathrm{KNO}_{3}$ and $\mathrm{K}_{2} \mathrm{SO}_{4}$ solutions in Fig.7. In the presence of $\mathrm{KNO}_{3}$, at low volumes up to $0.5 \mathrm{~mL}$, the sensitivity did not change, but it began to decline with increasing slope at higher volumes. However, even at low volumes in the presence of $\mathrm{K}_{2} \mathrm{SO}_{4}$, it was observed that the sensitivity decreased with increasing slope. This indicates that the ionic strength of the environment should be controlled in real complex specimens with high ionic strength. Another solution is to conduct sample analysis with a standard addition calibration curve based on the addition of the known standards of Se(IV).

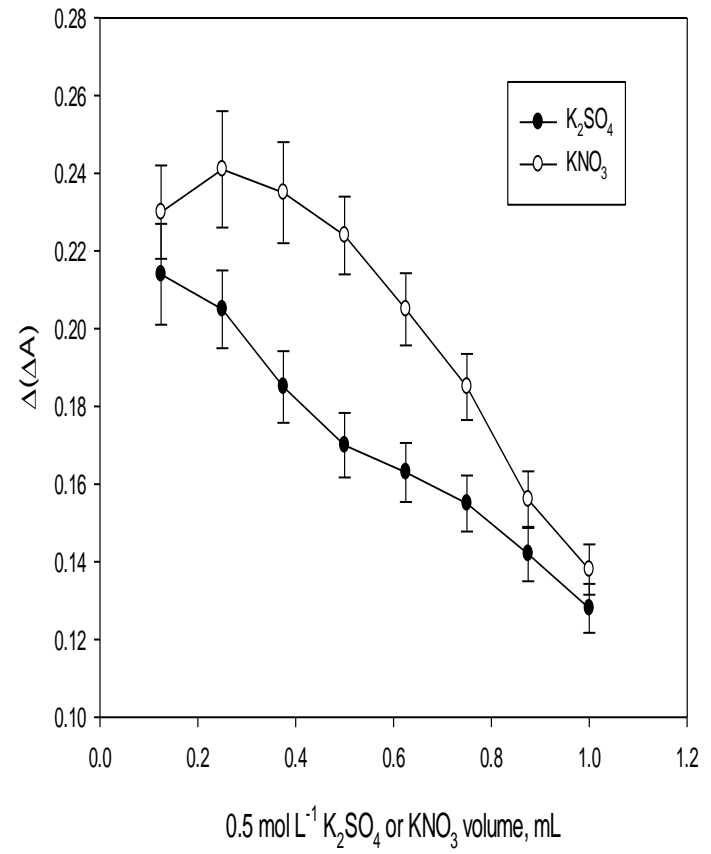

Figure 7. Effect of ionic strength of the medium on sensitivity. Optimal conditions: [Se(IV)]: $250 \mu \mathrm{g} \mathrm{L}^{-1}, \quad\left[\mathrm{H}_{2} \mathrm{SO}_{4}\right]: 0.075 \mathrm{~mol} \mathrm{~L} \mathrm{~L}^{-1}$, [PMA] $0.041 \mathrm{~mol} \mathrm{~L}^{-1},\left[\mathrm{H}_{2} \mathrm{PO}_{2}^{-}\right]: 5.0 \times 10^{-3} \mathrm{~mol} \mathrm{~L}^{-1},\left[\mathrm{Hg}^{2+}\right]$ : $7.5 \times 10^{-4} \mathrm{~mol} \mathrm{~L}^{-1}$, fixed-time: $20 \mathrm{~min}$, temperature: $70{ }^{\circ} \mathrm{C}$ at $680 \mathrm{~nm}$.

\subsection{Analytical figures of merit}

\subsubsection{Calibration curve, detection limit, accuracy and precision}

Monitoring the net absorbance change according to optimal reagent conditions, different $\mathrm{Se}(\mathrm{IV})$ standard calibration solutions for $\Delta(\Delta \mathrm{A})=$ $\left(\Delta \mathrm{A}_{\mathrm{C}}-\Delta \mathrm{A}_{0}\right)$ were sampled. The results show that the analytical signal against the concentration of $\mathrm{Se}(\mathrm{IV})$ in the range of $0.0125-1.0 \mu \mathrm{g} \mathrm{mL} \mathrm{m}^{-1}, \Delta(\Delta \mathrm{A})$, lies in a sufficiently wide linear range with a regression coefficient of 0.9981 in Fig. 8. In this calibration interval the least squares equation is as follows:

$\Delta(\Delta \mathrm{A})=(0.80 \pm 0.05) \times \mathrm{C}_{\mathrm{Se}(\mathrm{IV})}\left[\mu \mathrm{g} \mathrm{mL} \mathrm{L}^{-1}\right]+(0.014 \pm 0.001)\left(\mathrm{n}: 5, \mathrm{r}^{2}: 0.9981\right)$ 


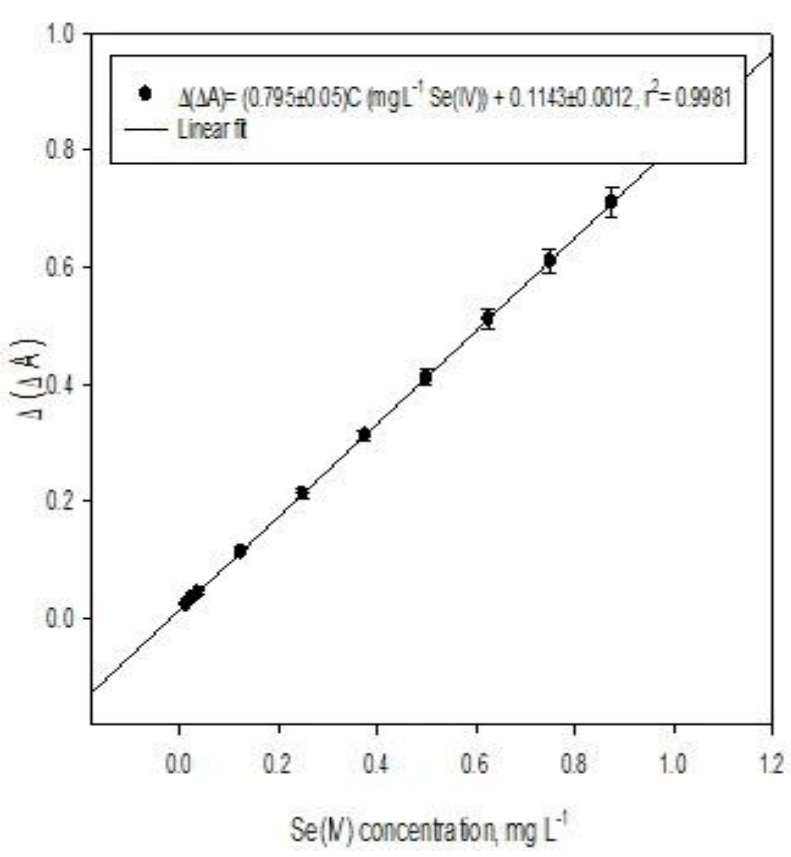

Figure 8. The calibration curve. Optimal conditions: [Se(IV)]: $250 \mu \mathrm{g} \mathrm{L}^{-1},\left[\mathrm{H}_{2} \mathrm{SO}_{4}\right.$ ]: $0.075 \mathrm{~mol} \mathrm{~L}^{-1}$, [PMA]: $0.041 \mathrm{~mol} \mathrm{~L}^{-1},\left[\mathrm{H}_{2} \mathrm{PO}_{2}^{-}\right]: 5.0 \times 10^{-3} \mathrm{~mol} \mathrm{~L}{ }^{-1},\left[\mathrm{Hg}^{2+}\right]$ : $7.5 \times 10^{-4} \mathrm{~mol} \mathrm{~L}^{-1}, 0.5 \mathrm{~mL}$ of $0.5 \mathrm{~mol} \mathrm{~L}{ }^{-1} \mathrm{KNO}_{3}$, fixed time: $20 \mathrm{~min}$, temperature: $70^{\circ} \mathrm{C}$ at $680 \mathrm{~nm}$.
The limits of detection and quantification of the present kinetic method (LOD and LOQ) was calculated by taking 3 - and 10-folds of the standard deviation of the signal for the ten replicate measurements of the blank solution without analyte, and found to be 3.6 and $12 \mu \mathrm{g} \mathrm{L} \mathrm{L}^{-1}$, respectively. Five replicate measurements were performed for different concentrations ranging from 0.0125 to $1.0 \mu \mathrm{g} \mathrm{mL} \mathrm{m}^{-1}$ and the percent recovery, relative error (RE) and relative standard deviation (RSD) values were found by substituting the analytical signals at the calibration equation. The detailed information is presented in Table 1. From the results, it can be stated that the proposed method is accurate and precise.

Table 1. The accuracy and precision of the five replicate measurement results of $\mathrm{Se}(\mathrm{IV})$ at different concentrations. Optimal conditions: $\left[\mathrm{H}_{2} \mathrm{SO}_{4}\right]: 0.075 \mathrm{~mol} \mathrm{~L}^{-1}$, [PMA]: $0.041 \mathrm{~mol} \mathrm{~L}^{-1},\left[\mathrm{H}_{2} \mathrm{PO}_{2}{ }^{-}\right]: 5.0 \times 10^{-3} \mathrm{~mol}$ $\mathrm{L}^{-1},\left[\mathrm{Hg}^{2+}\right] 7.5 \times 10^{-4} \mathrm{~mol} \mathrm{~L}^{-1}$, fixed time: $20 \mathrm{~min}$, temperature: $70^{\circ} \mathrm{C}$.

\begin{tabular}{cccccc}
\hline & \multicolumn{5}{c}{ By fixed time approach of 20 min at 680 nm } \\
\cline { 2 - 5 } $\mathrm{Se}(\mathrm{IV})$ & Added & Found $\pm \mathrm{SD}^{\mathrm{a}}$ & Recovery \% & RE \% & RSD $^{\mathrm{b}}$ \\
$\left(\mu \mathrm{g} \mathrm{L}^{-1}\right)$ & 25 & $24.65 \pm 0.80$ & 98.6 & -1.40 & 3.25 \\
& 100 & $99.35 \pm 1.48$ & 99.4 & -0.65 & 1.49 \\
& 250 & $251.90 \pm 1.76$ & 100.8 & 0.76 & 0.70 \\
& 750 & $748.65 \pm 2.80$ & 99.8 & -0.18 & 0.37 \\
\hline
\end{tabular}

${ }^{a}$ The average plus standard deviation of five repeated measurements (n: 5).

${ }^{\mathrm{b}}$ The percent relative error (RE \%).

${ }^{\mathrm{c}}$ The percent relative standard deviation (RSD \%).

\subsubsection{Selectivity}

To determine the selectivity of the kinetic method against interferents, the effect of possible interfering species on the rate of catalytic reaction was investigated by changing the concentration of interfering ions to keep the concentration of Se(IV) constant at $250 \mu \mathrm{g} \mathrm{L}^{-1}$ in Table 2. The tolerance limit has been defined as the concentration of interfering species that does not cause more than \pm $5.0 \%$ of relative error. The results are summarized in detail in Table 2. They indicate that all other interfering species, except for Te(IV), Bi(III), $\mathrm{Cu}$ (II) and $\mathrm{Sn}(\mathrm{IV})$ ions, do not significantly affect the analytical signal when selenium at the level of $250 \mu \mathrm{g} \mathrm{L}^{-1}$ was determined in a final volume of $10 \mathrm{~mL}$ under optimum reagent conditions. The effect of the $\mathrm{Te}(\mathrm{IV}), \mathrm{Cu}$ (II) and $\mathrm{Bi}$ (III) ions has been increased to a tolerance ratio ranging from 35 to 70 with addition of thiourea. The interference of $\mathrm{Sn}(\mathrm{IV})$ was improved to a tolerance ratio of 50-fold with the addition of $\mathrm{NH}_{4} \mathrm{~F}$. Similar errors resulting from positive and negative interactions between analyte and matrix in real samples can be 
minimized by using the calibration curve approach based on spiking at three concentration levels around quantification limit.

Table 2. The effect of potential interfering species on the determination of $250 \mu \mathrm{g} \mathrm{L}^{-1} \mathrm{Se}(\mathrm{IV})$ by the current kinetic method. Optimal conditions: $\left[\mathrm{H}_{2} \mathrm{SO}_{4}\right]: 0.075 \mathrm{~mol} \mathrm{~L}^{-1}$, [PMA]: $0.041 \mathrm{~mol} \mathrm{~L}^{-1},\left[\mathrm{H}_{2} \mathrm{PO}_{2}^{-}\right]: 5.0 \times$ $10^{-3} \mathrm{~mol} \mathrm{~L}^{-1},\left[\mathrm{Hg}^{2+}\right] 7.5 \times 10^{-4} \mathrm{~mol} \mathrm{~L}^{-1}$, fixed time: $20 \mathrm{~min}$, temperature: $70^{\circ} \mathrm{C}$.

\begin{tabular}{lc}
\hline \multicolumn{1}{c}{ Interfering species } & $\begin{array}{c}\text { Tolerance ratio, } \\
{\left[{ }^{a} \mathrm{C}_{\text {iyon }} / \mathrm{C}_{\mathrm{Se}(\mathrm{IV})}\right]}\end{array}$ \\
\hline $\mathrm{NH}_{4}{ }^{+}, \mathrm{Na}(\mathrm{I}), \mathrm{K}(\mathrm{I}), \mathrm{Li}(\mathrm{I}), \mathrm{Ca}(\mathrm{II}), \mathrm{Mg}(\mathrm{II}), \mathrm{Sr}(\mathrm{II})$ and $\mathrm{Ba}(\mathrm{II})$ & $>1500$ \\
$\mathrm{Cr}(\mathrm{III}), \mathrm{Zn}(\mathrm{II}), \mathrm{Al}(\mathrm{III}), \mathrm{C}_{2} \mathrm{O}_{4}{ }^{2-}, \mathrm{F}^{-}$, thiosemicarbazide, $\mathrm{CH}_{3} \mathrm{COO}^{-}{ }^{-}$and $\mathrm{Cl}^{-}$ & $600-1200$ \\
Borate, citrate, tartrate, thiourea, $\mathrm{SO}_{4}{ }^{2-}, \mathrm{Ni}(\mathrm{II}), \mathrm{Cd}(\mathrm{II}), \mathrm{HCO}_{3}{ }^{-}, \mathrm{ClO}_{3}{ }^{-}$and $\mathrm{Ce}(\mathrm{III})$ & $350-500$ \\
$\mathrm{~Pb}(\mathrm{II}), \mathrm{Sn}(\mathrm{II}), \mathrm{Mn}(\mathrm{II}), \mathrm{As}(\mathrm{III}), \mathrm{NO}_{3}{ }^{-}, \mathrm{HPO}_{4}{ }^{2-}$ and $\mathrm{ClO}_{4}{ }^{-}$ & $135-300$ \\
$\mathrm{SCN}^{-}, \mathrm{W}(\mathrm{VI}), \mathrm{Se}(\mathrm{VI}), \mathrm{Co}(\mathrm{II})$ and $\mathrm{Sb}(\mathrm{III})$ & $75-125$ \\
$\mathrm{SO}_{3}{ }^{2-}, \mathrm{Mn}(\mathrm{II}), \mathrm{Fe}(\mathrm{II}), \mathrm{NO}_{2}{ }^{-}, \mathrm{IO}_{3}{ }^{-}, \mathrm{Cu}(\mathrm{I})$ and $\mathrm{Br}^{-}$ & $35-70$ \\
$\mathrm{Cr}^{-}(\mathrm{VI}), \mathrm{S}_{2} \mathrm{O}_{3}{ }^{2-}, \mathrm{Hg}(\mathrm{I}), \mathrm{CN}^{-}, \mathrm{I}^{-}$and $\mathrm{V}(\mathrm{IV})$ & $25-35$ \\
$\mathrm{Fe}(\mathrm{III}), \mathrm{V}(\mathrm{V}), \mathrm{Ce}(\mathrm{IV}), \mathrm{As}(\mathrm{V})$ and $\mathrm{Sb}(\mathrm{V})$ & $15-25$ \\
$\mathrm{Te}(\mathrm{IV})^{\mathrm{b}}, \mathrm{Bi}(\mathrm{III})^{\mathrm{c}}$ and $\mathrm{Cu}(\mathrm{II})^{\mathrm{c}}$ & $5-10(35,50-75)$ \\
$\mathrm{Sn}(\mathrm{IV})^{\mathrm{d}}$ & $3(>50)$ \\
\hline
\end{tabular}

${ }^{a} \mathrm{C}$ represents the concentration in $\mu \mathrm{g} \mathrm{L}{ }^{-1}$.

${ }^{\mathrm{b}}$ The interference of Te(IV) may be greatly suppressed by addition of $1.5 \mathrm{~mL}$ of $0.01 \%(\mathrm{w} / \mathrm{v})$ thiourea solution as a masking agent.

${ }^{\mathrm{c}}$ The interference of $\mathrm{Cu}(\mathrm{II})$ and $\mathrm{Bi}(\mathrm{III})$ ions may be greatly suppressed by addition of $1.2 \mathrm{~mL}$ of $0.02 \%$ (w/v) thiourea solution as masking agent.

${ }^{\mathrm{d}}$ The interference of $\mathrm{Sn}(\mathrm{IV})$ may be greatly suppressed by addition of $1.0-2.0 \mathrm{~mL} 0.025 \%(\mathrm{w} / \mathrm{v}) \mathrm{NH}_{4} \mathrm{~F}$ as masking agent.

\subsubsection{Analytical applications of the method}

At initial, the method was applied to samples taken from hot- and cold-spring waters after submitting to certain pretreatments. Samples were treated by using directly kinetic method for analysis of $\mathrm{Se}(\mathrm{IV})$. Then, for total selenium analysis, samples were treated by boiling with 4.0$5.0 \mathrm{~mol} \mathrm{~L}{ }^{-1} \mathrm{HCl}$ at $85-90{ }^{\circ} \mathrm{C}$ for $30 \mathrm{~min}$, for prereduction of $\mathrm{Se}(\mathrm{VI})$ to $\mathrm{Se}(\mathrm{IV})$. The total $\mathrm{Se}$ contents of samples were calculated from the difference between total $\mathrm{Se}$ and free $\mathrm{Se}(\mathrm{IV})$ amounts obtained by using the kinetic method with and without prereduction. To ensure the accuracy and precision of the method, total selenium levels were also monitored after conversion to hydride with $\mathrm{NaBH}_{4}$ in $\mathrm{HCl}$ medium after acidification. From the results obtained by both methods in Table 3, it can be concluded that the current method is as accurate and precision as the routine HG AAS method. 
Table 3. Determination and speciation analysis of inorganic Se(IV), Se(VI) and total selenium levels in hotand cold-spring waters by both kinetic method and HG AAS (n: 4).

\begin{tabular}{|c|c|c|c|c|c|c|c|c|c|c|c|c|c|c|c|c|}
\hline \multirow{3}{*}{$\begin{array}{l}\text { Sample } \\
\text { s }\end{array}$} & \multicolumn{12}{|c|}{ By the present kinetic method } & \multicolumn{4}{|c|}{ By HG AAS } \\
\hline & \multicolumn{2}{|c|}{$\begin{array}{c}\text { Spiking level } \\
\left(\mu \mathrm{g} \mathrm{L}^{-1}\right)\end{array}$} & \multicolumn{3}{|c|}{$\begin{array}{l}\text { a Found } \\
\left(\mu \mathrm{g} \mathrm{L}^{-1}\right)\end{array}$} & \multicolumn{3}{|c|}{$\begin{array}{c}{ }^{\mathrm{b}} \text { Recovery } \\
\%\end{array}$} & \multicolumn{2}{|c|}{$\begin{array}{l}{ }^{\mathrm{d}} \mathrm{RE} \\
\%\end{array}$} & \multicolumn{2}{|c|}{$\begin{array}{c}{ }^{\mathrm{d}} \mathrm{RSD} \\
\%\end{array}$} & $\begin{array}{l}{ }^{\mathrm{a}} \text { Found } \\
\left(\mu \mathrm{gL}^{-1}\right)\end{array}$ & $\begin{array}{l}\text { 'Reco- } \\
\text { very\% }\end{array}$ & $\begin{array}{l}{ }^{\mathrm{d}} \mathrm{RE} \\
\%\end{array}$ & ${ }^{\mathrm{d}} \mathrm{RSD} \%$ \\
\hline & $\mathrm{Se}(\mathrm{IV})$ & $\mathrm{Se}(\mathrm{VI})$ & $\mathrm{Se}(\mathrm{IV})$ & $\mathrm{Se}(\mathrm{VI})$ & Total Se & $\mathrm{Se}(\mathrm{IV})$ & $\mathrm{Se}(\mathrm{VI})$ & $\begin{array}{c}\text { Total } \\
\mathrm{Se}\end{array}$ & $\mathrm{Se}(\mathrm{IV})$ & $\begin{array}{c}\text { Total } \\
\mathrm{Se}\end{array}$ & $\begin{array}{c}\mathrm{Se} \\
\text { (IV) }\end{array}$ & $\begin{array}{c}\text { Total } \\
\text { Se }\end{array}$ & & Tot & & \\
\hline \multirow{4}{*}{$\begin{array}{l}\text { Hot- } \\
\text { spring } \\
\text { water }\end{array}$} & - & - & $\begin{array}{c}5.2 \pm \\
0.3\end{array}$ & 9.3 & $\begin{array}{r}14.5 \\
\pm 0.5\end{array}$ & - & - & - & - & - & 5.4 & 3.6 & $\begin{array}{r}16.1 \\
\pm 0.3\end{array}$ & - & - & 1.6 \\
\hline & 10 & 100 & $\begin{array}{r}15.3 \\
\pm 0.6\end{array}$ & 109.5 & $\begin{array}{l}124.7 \\
\pm 0.5\end{array}$ & $96 \pm 3$ & $99 \pm 4$ & $\begin{array}{c}99 \pm \\
3\end{array}$ & -2.7 & -0.6 & 6.8 & 8.9 & $\begin{array}{l}125.7 \\
\pm 2.6\end{array}$ & 99.6 & -0.4 & 2.1 \\
\hline & 100 & 10 & $\begin{array}{l}105.4 \\
\pm 2.9\end{array}$ & 19.4 & $\begin{array}{l}125 \\
\pm 3\end{array}$ & $\begin{array}{c}100 \pm \\
1\end{array}$ & $96 \pm 1$ & $\begin{array}{c}99 \pm \\
1\end{array}$ & -0.3 & -2.2 & 7.5 & 7.9 & $\begin{array}{l}126.3 \\
\pm 2.5\end{array}$ & 100.2 & 0.2 & 2.0 \\
\hline & 100 & 100 & $\begin{array}{l}105.4 \\
\pm 2.9\end{array}$ & 109.5 & $\begin{array}{l}215 \\
\pm 3\end{array}$ & $99 \pm 2$ & $99 \pm 4$ & $\begin{array}{c}99 \pm \\
3\end{array}$ & -0.6 & -1.4 & 8.4 & 6.5 & $\begin{array}{l}215.7 \\
\pm 3.6\end{array}$ & 99.8 & -0.2 & 1.7 \\
\hline \multirow{4}{*}{$\begin{array}{l}\text { Cold- } \\
\text { spring } \\
\text { water }\end{array}$} & - & - & $\begin{array}{c}4.5 \\
\pm 0.1\end{array}$ & 11.2 & $\begin{array}{r}15.7 \\
\pm 0.1\end{array}$ & - & - & - & - & - & 4.0 & 4.7 & $\begin{array}{r}15.4 \\
\pm 0.3\end{array}$ & - & - & 2.1 \\
\hline & 10 & 100 & $\begin{array}{r}14.4 \\
\pm 0.1\end{array}$ & 111.3 & $\begin{array}{l}115.8 \\
\pm 0.1\end{array}$ & $\begin{array}{l}96 \\
\pm 3\end{array}$ & $\begin{array}{l}99 \\
\pm 4\end{array}$ & $\begin{array}{l}99 \\
\pm 3\end{array}$ & -2.7 & -0.6 & 6.8 & 8.9 & $\begin{array}{l}125.5 \\
\pm 3.2\end{array}$ & 100.1 & 0.9 & 2.6 \\
\hline & 100 & 10 & $\begin{array}{c}106 \\
\pm 0.1\end{array}$ & 21.3 & $\begin{array}{l}115.7 \\
\pm 0.1\end{array}$ & $\begin{array}{c}100 \pm \\
1\end{array}$ & $\begin{array}{l}96 \\
\pm 1\end{array}$ & $\begin{array}{l}99 \\
\pm 1\end{array}$ & -0.3 & -2.2 & 7.5 & 7.9 & $\begin{array}{l}125.8 \\
\pm 2.9\end{array}$ & 99.7 & -0.3 & 2.3 \\
\hline & 100 & 100 & $\begin{array}{l}114.1 \\
\pm 0.1\end{array}$ & 111.3 & $\begin{array}{l}215.9 \\
\pm 0.1\end{array}$ & $\begin{array}{l}99 \\
\pm 2\end{array}$ & $\begin{array}{l}99 \\
\pm 4\end{array}$ & $\begin{array}{r}99 \\
\pm 3\end{array}$ & -0.6 & -1.4 & 8.4 & 6.5 & $\begin{array}{l}215.7 \\
\pm 3.6\end{array}$ & 99.8 & -0.2 & 1.7 \\
\hline
\end{tabular}

${ }^{\mathrm{a}}$ The average \pm standard deviation of replicate measurement results found using both kinetic method and HG AAS.

${ }^{\mathrm{b}}$ The spiking recoveries for analysis of $\mathrm{Se}(\mathrm{IV}), \mathrm{Se}(\mathrm{VI})$ and total selenium by the present kinetic method were defined by the following equation: spiking recovery $\%=C_{\text {found }}-C_{\text {real }} / C_{\text {added }} \times 100$. Here, $C_{\text {found }}, C_{\text {real }}$ and $C_{\text {added }}$ are the concentration of analyte after the addition of a known amount of standard in the real sample, the concentration of the analyte in the real sample and the concentration of a known amount of standard spiked to the real sample, respectively.

The present kinetic method for validation was applied to two separate SRMs given in Table 4 after sample preparation to analysis with two different wet dissolution approaches and conversion of $\mathrm{Se}(\mathrm{VI})$ to $\mathrm{Se}(\mathrm{IV})$ by boiling sample solutions at $85-90{ }^{\circ} \mathrm{C}$ with $4.0-4.5 \mathrm{~mol} \mathrm{~L}^{-1} \mathrm{HCl}$. To ensure the accuracy of the method, two certified samples were also analyzed by HG AAS, which is an independent comparison method after prereduction with $\mathrm{NaBH}_{4}$, by thoroughly dissolving and homogenizing the samples in $\mathrm{H}_{2} \mathrm{SO}_{4}$ by under ultrasonic effect. The results were quite consistent with the certified values of selenium. The kinetic method after wet digestion with $\mathrm{H}_{2} \mathrm{SO}_{4}$ appears to be somewhat questionable in terms of both accuracy and precision. This indicates that the selenium present in the sample matrix cannot be fully solubilized and released. It can be said that the result obtained with the other digestion approach is highly compatible with that of the HG AAS, and the results obtained with both methods are quite consistent with the certified values in terms of accuracy and precision. The kinetic procedure was applied to two different SRMs given in Table 4. The results are in good agreement with the selenium values. The relative standard deviations for solid samples were in the range of $5.8-8.7 \%$ as a measure of precision. The precision (as RSD\%, $\mathrm{n}: 5)$ for both SRMs varies between 5.0-6.62\%. On the other hand, the precision of HG AAS analysis results was in range of 4.57-5.07\%. 
Table 4. Total selenium levels found in the selected CRMs by the present kinetic method and HG AAS (n: 5)

\begin{tabular}{|c|c|c|c|c|c|c|c|c|c|c|c|c|}
\hline \multirow{2}{*}{\multicolumn{2}{|c|}{ Samples }} & \multicolumn{6}{|c|}{ By the present kinetic method } & \multirow{2}{*}{\multicolumn{3}{|c|}{$\begin{array}{c}\text { By HG AAS } \\
\text { After ultrasonic } \\
\text { dissolution in } \mathrm{H}_{2} \mathrm{SO}_{4} \\
\text { medium } \\
\end{array}$}} & \multirow{2}{*}{\multicolumn{2}{|c|}{$\begin{array}{c}\text { The statistically } \\
\text { observed t- and } \\
\text { F-values }\end{array}$}} \\
\hline & & \multicolumn{3}{|c|}{$\begin{array}{l}\text { After wet digestion with } \\
\qquad \mathrm{H}_{2} \mathrm{SO}_{4}\end{array}$} & \multicolumn{3}{|c|}{$\begin{array}{c}\text { After wet digestion with } \\
\text { mixture of } \mathrm{HNO}_{3}, \mathrm{H}_{2} \mathrm{SO}_{4} \text { and } \\
\qquad \mathrm{H}_{2} \mathrm{O}_{2}\end{array}$} & & & & & \\
\hline \multicolumn{2}{|c|}{ Certified value } & Found & $\begin{array}{c}\mathrm{RS} \\
\mathrm{D} \\
\%\end{array}$ & RE \% & Found & $\begin{array}{c}\mathrm{RSD} \\
\%\end{array}$ & $\mathrm{RE} \%$ & Found & $\begin{array}{c}\mathrm{RSD} \\
\%\end{array}$ & $\begin{array}{c}\mathrm{RE} \\
\%\end{array}$ & $\begin{array}{c}\mathrm{t}- \\
\text { value }\end{array}$ & $\begin{array}{l}\text { F- } \\
\text { value }\end{array}$ \\
\hline $\begin{array}{c}\text { GBW } \\
07605 \text { Tea }\end{array}$ & $\begin{array}{l}0.072 \\
\mu \mathrm{g} \mathrm{g}^{-1}\end{array}$ & $\begin{array}{c}0.068 \\
\pm 0.004 \\
\mu^{-1 g^{-1}}\end{array}$ & 6.6 & -5.9 & $\begin{array}{c}0.070 \\
\pm 0.004 \\
\mu^{-1} g^{-1}\end{array}$ & 5.4 & -2.9 & $\begin{array}{c}0.071 \\
\pm 0.004 \\
\mu \mathrm{g} \mathrm{g}^{-1}\end{array}$ & 5.1 & -1.4 & $\begin{array}{c}0.82 \\
0.30\end{array}$ & $\begin{array}{l}1.56 \\
1.11\end{array}$ \\
\hline $\begin{array}{l}\text { LGC } 6010 \\
\text { Hard } \\
\text { drinking } \\
\text { water }\end{array}$ & $\begin{array}{c}9.3 \\
\mu \mathrm{g} \mathrm{L} \mathrm{L}^{-1}\end{array}$ & $\begin{array}{l}\mu \mathrm{g} \mathrm{g}^{-1} \\
9.5 \\
\pm 0.5 \\
\mu \mathrm{g} \mathrm{L}^{-1}\end{array}$ & 5.7 & +2.1 & $\begin{array}{l}\mu \mathrm{g} \mathrm{g}^{-1} \\
9.4 \\
\pm 0.5 \\
\mu \mathrm{g} \mathrm{L}^{-1}\end{array}$ & 5.0 & +1.1 & $\begin{array}{l}\mu \mathrm{g} \mathrm{g}^{-1} \\
9.4 \\
\pm 0.4 \\
\mu \mathrm{g} \mathrm{L}^{-1}\end{array}$ & 4.6 & +1.1 & $\begin{array}{l}0.23 \\
0.25\end{array}$ & $\begin{array}{l}1.58 \\
1.19\end{array}$ \\
\hline
\end{tabular}

a The statistical t- and F-values observed in the detection of determinate and indeterminate errors for the present kinetic and independent HG-AAS methods for 8 degrees of freedom at 95\% confidence level where the critical t- and F-values are 2.31 and 6.39 , respectively.

Because of the importance of selenium consumption by foods and beverages such as tea for healthy life, the present method was applied to different brand black and green tea samples after two different digestion approaches. The sensitive and selective method commonly used for total Se analysis such as HG AAS to ensure the accuracy of the method was used in parallel after the ultrasonicbased dissolution approach in $\mathrm{H}_{2} \mathrm{SO}_{4}$ medium, and the results were found to be highly consistent with those of the present kinetic method. The results were extensively presented in Table 5. A report in literature has shown that the total Se and Se(IV) levels in four commercial tea leaves supplied from different regions of China varied from 191 to $724 \mu \mathrm{g} \mathrm{kg}^{-1}$ and from 173 to $613 \mu \mathrm{g} \mathrm{kg} \mathrm{kg}^{-1}$ respectively ${ }^{16}$, which are consistent with our results (ranging from 281 to $708 \mu \mathrm{g} \mathrm{kg}^{-1}$ ). Another research group in Turkey has determined a total selenium level of $68 \mu \mathrm{g} \mathrm{kg}^{-1}$ with a standard deviation of $5 \mu \mathrm{g} \mathrm{kg}^{-1}$ in a black tea sample supplied from the market from Turkey ${ }^{10}$. In a similar way, from analysis of the samples by means of ICP OES, it has been observed that total selenium levels are $280 / 1250 \mu \mathrm{g} \mathrm{kg}^{-1}$ and $1093 / 1668 \mu \mathrm{g} \mathrm{kg}^{-1}$ respectively in Turkish green and black tea samples with and without lemon. It is clear that lemon addition synergistically increases the selenium concentration in both the black teas and green teas ${ }^{42}$. Selenium is a trace mineral that is essential to good health but required only in small amounts. Selenium is incorporated into proteins to make selenoproteins, which are important antioxidant enzymes. The antioxidant properties of selenoproteins help prevent cellular damage from free radicals. Free radicals are natural by-products of oxygen metabolism that may contribute to the development of chronic diseases such as cancer and heart disease. Other selenoproteins help to regulate thyroid function and play a role in the immune system. In this sense, it can be concluded that citric acid in lemon leads to an improvement in antioxidant property of selenium or selenoprotein in tea. 
Table 5. Total Se levels found in different tea samples by the present kinetic method and HG AAS (n: 5).

\begin{tabular}{|c|c|c|c|c|c|c|c|c|c|}
\hline \multirow{3}{*}{ Samples } & \multicolumn{6}{|c|}{ By the present kinetic method } & \multirow{2}{*}{\multicolumn{3}{|c|}{$\begin{array}{c}\text { By HG AAS } \\
\text { After ultrasonic dissolution in } \\
\mathrm{H}_{2} \mathrm{SO}_{4} \text { medium } \\
\end{array}$}} \\
\hline & \multicolumn{3}{|c|}{ After wet digestion with $\mathrm{H}_{2} \mathrm{SO}_{4}$} & \multicolumn{3}{|c|}{$\begin{array}{l}\text { After wet digestion with mixture of } \\
\qquad \mathrm{HNO}_{3}, \mathrm{H}_{2} \mathrm{SO}_{4} \text { and } \mathrm{H}_{2} \mathrm{O}_{2}\end{array}$} & & & \\
\hline & $\begin{array}{l}\text { Added } \\
\left(\mu \mathrm{g} \mathrm{L}^{-1}\right)\end{array}$ & $\begin{array}{l}\text { aFound } \\
\left(\mu g^{-1}\right)\end{array}$ & $\begin{array}{c}{ }^{\mathrm{b}} \text { Recovery } \\
(\%)\end{array}$ & $\begin{array}{c}\text { Added } \\
\left(\mu \mathrm{g} \mathrm{L}^{-1}\right)\end{array}$ & $\begin{array}{l}{ }^{\text {a} F o u n d ~} \\
\left(\mu \mathrm{g} \mathrm{L}^{-1}\right)\end{array}$ & $\begin{array}{c}{ }^{b} \text { Recovery } \\
(\%)\end{array}$ & $\begin{array}{l}\text { Added } \\
\left(\mu \mathrm{g} \mathrm{L}^{-1}\right)\end{array}$ & $\begin{array}{l}\text { aFound } \\
\left(\mu g \mathrm{~L}^{-1}\right)\end{array}$ & $\begin{array}{c}{ }^{\mathrm{b}} \text { Recovery } \\
(\%)\end{array}$ \\
\hline \multirow{3}{*}{ Black teal } & - & $28 \pm 2$ & - & - & $32 \pm 2$ & - & - & $31 \pm 3$ & - \\
\hline & 10 & $38 \pm 2$ & 97.0 & 10 & $42 \pm 2$ & 97.0 & 10 & $40 \pm 2$ & 97.0 \\
\hline & 50 & $77 \pm 5$ & 97.4 & 50 & $81 \pm 5$ & 98.0 & 50 & $81 \pm 5$ & 99.8 \\
\hline \multirow{3}{*}{ Black tea2 } & - & $32 \pm 3$ & - & - & $34 \pm 2$ & - & - & $35 \pm 2$ & - \\
\hline & 10 & $42 \pm 3$ & 98.0 & 10 & $44 \pm 4$ & 97.0 & 10 & $45 \pm 3$ & 94.0 \\
\hline & 50 & $82 \pm 5$ & 99.6 & 50 & $84 \pm 5$ & 99.0 & 50 & $85 \pm 6$ & 99.6 \\
\hline \multirow{3}{*}{$\begin{array}{c}\text { Green } \\
\text { teal }\end{array}$} & - & $63 \pm 5$ & - & - & $67 \pm 4$ & - & - & $68 \pm 4$ & - \\
\hline & 25 & $89 \pm 6$ & 97.0 & 25 & $91 \pm 6$ & 97.0 & 25 & $93 \pm 7$ & 97.0 \\
\hline & 50 & $114 \pm 8$ & 98.0 & 50 & $117 \pm 8$ & 98.0 & 50 & $118 \pm 8$ & 98.0 \\
\hline \multirow{3}{*}{$\begin{array}{c}\text { Green } \\
\text { tea2 }\end{array}$} & - & $56 \pm 4$ & - & - & $58 \pm 4$ & - & - & $58 \pm 4$ & - \\
\hline & 25 & $90 \pm 6$ & 97.0 & 25 & $90 \pm 6$ & 97.0 & 25 & $90 \pm 6$ & 97.0 \\
\hline & 50 & $116 \pm 9$ & 98.0 & 50 & $116 \pm 9$ & 98.0 & 50 & $116 \pm 9$ & 98.0 \\
\hline \multirow{3}{*}{$\begin{array}{l}\text { Green } \\
\text { tea3 }\end{array}$} & - & $71 \pm 6$ & - & - & $72 \pm 6$ & - & - & $72 \pm 5$ & - \\
\hline & 25 & $95 \pm 6$ & 97.0 & 25 & $98 \pm 6$ & 97.0 & 25 & $98 \pm 6$ & 97.0 \\
\hline & 50 & $128 \pm 9$ & 98.0 & 50 & $121 \pm 8$ & 98.0 & 50 & $121 \pm 8$ & 98.0 \\
\hline
\end{tabular}

${ }^{a}$ The average \pm standard deviation of replicate measurement results found using both kinetic method and HG AAS

${ }^{\mathrm{b}}$ The spiking recoveries for analysis of total Se by both the present kinetic method and HG-AAS were defined by the following equation: spiking recovery $\%=C_{\text {found }}-C_{\text {real }} / C_{\text {added }} \times 100$ here, $C_{\text {found }}, C_{\text {real }}$ and $C_{\text {added }}$ are the concentration of analyte after the addition of a known amount of standard in the real sample, the concentration of the analyte in the real sample and the concentration of a known amount of standard spiked to the real sample, respectively.

\section{Conclusions}

A spectrophotometry in visible region with selection of an indicator suitable for analyte is a comparatively low cost, robust and easy-to-operate analytical technique that is readily available in most analytical research laboratories. In the selected kinetic mode, it is a fast, reproducible and versatile technique with analytical frequency of nine samples (three samples plus six calibrations standard) per $20 \mathrm{~min}$. Because the developed method is based on a Se-activated indicator reaction and the final intermediate product is stable for fixed time of $20 \mathrm{~min}$ even at a temperature of $70{ }^{\circ} \mathrm{C}$, this detection tool can be efficiently used for the fast, accurate and reliable analysis of selenium species. In addition, the method allows a detection of low levels of Se(IV) up to $3.6 \mu \mathrm{g} \mathrm{L}^{-1}$ in a linear working range of 80 -fold without need to a separation/preconcentration step. So, the determination of inorganic selenium species in other sample matrices can be performed even at low concentrations without any matrix effect. Finally, the method can be considered as an alternative to expensive, time-consuming/tedious and complex analytical techniques such as ICP MS, ICP OES, ET AAS or GF AAS, HG AAS, HG AFS, and HG AFS in combination with CE or LC. Moreover, these detection techniques require expert-users in his/her area as well as poor precision and low recovery at low concentrations. Also, the detection limit of the method is especially comparable to most of the similar spectrophotometric and kinetic spectrophotometric methods reported in the literature in terms of linear working range, sensitivity, selectivity and reproducibility. The only disadvantage of the method is that the indicator reaction takes place at high temperature $\left(70^{\circ} \mathrm{C}\right)$ and long time $(20 \mathrm{~min})$ limiting sampling rate related to kinetic analysis of samples.

\section{Acknowledgements}

The authors are grateful to the Commission of Scientific Research Projects, University of Cumhuriyet, Sivas, Turkey for partial financial support through project number of F-228.

Authors have no financial relationship with the organization that sponsored the research.

\section{References}

[1] Ochsenkühn-Petropoulou, M., Tsopelas, F., Speciation analysis of selenium using voltammetric techniques, Anal. Chim. Acta 467 (1-2) (2002) 167-178. https://doi.org/10.1016/S0003-2670(02)00091-0.

[2] Lu, C. Y., Yan, X. P., Capillary electrophoresis online coupled with hydride generation-atomic 
fluorescence spectrometry for speciation analysis of selenium, Electrophoresis, 26 (1) (2005) 155-160. https://doi.org/10.1002/elps.200406102.

[3] World Health Organization (WHO), Selenium in drinking-water. WHO Press, World Health Organization, Geneva, Switzerland, 2011. https://www.who.int/water_sanitation_health/dwq/che micals/selenium.pdf.

[4] Huerta, V. D., Sánchez, M. L. F., Sanz-Medel, A., An attempt to differentiate HPLC-ICP-MS selenium speciation in natural and selenised Agaricus mushrooms using different in natural and selenised Agaricus mushrooms using different, Anal. Bioanal. Chem. 384 (4) (2006) 902-907. https://doi.org/10.1007/s00216005-0174-7.

[5] Yuan, C., Gao, E., He, B., Jiang, G., Arsenic species and leaching characters in tea (Camellia sinensis), Food Chem. Toxicol. 45 (12) (2007) 2381-2389. https://doi.org//10.1016/j.fct.2007.06.015.

[6] Jha, A., Mann, R. S., Balachandran, R., Tea: A refreshing beverage, Indian Food Ind. 15 (1996) 22-29.

[7] Huang, C., Hu, B., He, M., Duan, J., Organic and inorganic selenium speciation in environmental and biological samples by nanometer-sized materials packed dual-column separation preconcentration on-line coupled with ICP-MS, J. Mass Spectrom. 43 (3) (2008) 336-345. https://doi.org/10.1002/jms.1321.

[8] Altunay, N., Gürkan, R., Güneş, M., Ultrasound assisted extraction and spectrophotometric determination of trace selenium in water, food and vegetable samples, Anal. $\begin{array}{lllll}\text { Methods. } & 8 & \text { (46) (2016) 8208-8218. }\end{array}$ https://doi.org/10.1039/C6AY02638A.

[9] Ahmed, M. J., Islam, M. T., Nime, M. J., A highly selective and sensitive spectrophotometric method for the determination of selenium using 2-hydroxy-1napthaldehyde-orthoaminophenol, Anal. Methods. 7 (18) (2015) 7811-7823. https://doi.org/10.1039/C5AY01311A.

[10] Tuzen, M., Saygi, K. O., Soylak, M., Separation and speciation of selenium in food and water samples by the combination of magnesium hydroxide co-precipitationgraphite furnace atomic absorption spectrometric determination, Talanta $71 \quad$ (2007) 424-429. https://doi.org/10.1016/j.talanta.2006.04.016.

[11] Panhwar, A. H., Tuzen, M., Kazi, T. G., Ultrasonic assisted dispersive liquid-liquid microextraction method based on deep eutectic solvent for speciation, preconcentration and determination of selenium species (IV) and (VI) in water and food samples, Talanta 175
(2017)

$352-358$

https://doi.org/10.1016/j.talanta.2017.07.063.

[12] Santos, E. J., Oliveira, E., Evaluation of Arsenic and Selenium in Brazilian Soluble Coffee by Inductively Coupled Plasma Optical Emission Spectrometry with Hydride Generation, Brazil. Arch. Biol. Technol. 44 (3) (2001) 233-238. https://doi.org/10.1590/S151689132001000300003.

[13] Anthemidis, A. N., Determination of Selenium (IV) in Natural Waters by HG-AAS Using an Integrated Reaction Chamber Gas-Liquid Separator, Spectrosc. Lett. $\quad 39 \quad$ (6) (2006) 699-711. https://doi.org/10.1080/00387010600934519.

[14] Arain, M. A., Khuhawar, M. Y., Bhanger, M. I., Liquid chromatographic determination of selenium in vegetables and tea leaves as 2,1,3-benzoselenaiazole, J. Chem. Soc. Pak. 21 (2) (1999) 137-140. https://www.jcsp.org.pk/ViewByVolume.aspx?v=72\&i =VOLUME 21, NO2, JUN 1999.

[15] Yoshida M, Kimura Y, Abe M, Ando T, Tachi H, Fukunaga K. Quantitative evaluation of selenium contained in tea by high performance liquid chromatography, J. Nutr. Sci. Vitaminol. (Tokyo). 47 (3) (2001) 248-252. https://doi.org/10.3177/jnsv.47.248.

[16] Zhou, Q., Lei, M., Li, J., Wang, M., Zhao, D., Xing, A., Zhao, K., Selenium speciation in tea by dispersive liquid-liquid microextraction coupled to highperformance liquid chromatography after derivatization with 2,3-diaminonaphthalene, J. Sep. Sci. 38 (9) (2015) 1577-1583. https://doi.org/10.1002/jssc.201401373.

[17] Zhou, Q., Lei, M., Li, J., Wang, M., Zhao, D., Xing, A., Zhao, K., Selenium speciation in tea by dispersive liquid-liquid microextraction coupled to highperformance liquid chromatography after derivatization with 2,3-diaminonaphthalene, J. Sep. Sci. 38 (9) (2015) 1577-1583. https://doi.org/10.1002/jssc.201401373.

[18] Keyvanfard, M., Sharifian, A., Kinetic spectrophotometric method for the determination of selenium(iv) by its catalytic effect on the reduction of spadns by sulphide in micellar media, J. Anal. Chem. 61 (6) (2006) 596-600. https://doi.org/10.1134/S1061934806060153.

[19] Gürkan, R., Ulusoy, H. I., The investigation of a novel indicator system for trace determination and speciation of selenium in natural water samples by kinetic spectrophotometric detection, Bull. Korean Chem. Soc. $31 \quad$ (7) (2010) 1907-1914. https://doi.org/10.5012/bkcs.2010.31.7.1907. 
[20] Ensafi, A. A., Lemraski, M. S., Highly Sensitive Spectrophotometric Reaction Rate Method for the Determination of Selenium Based on the Catalytic Reduction of Sulfonazo by Sulfide, Anal. Lett. 37 (12) (2004) 2469-2483. https:/doi.org/10.1081/AL200029374.

[21] Gürkan, R., Ulusoy, H. I., Akçay, M., Bulut, P., A novel indicator system for catalytic spectrophotometric determination and speciation of inorganic selenium species (Se(IV), $\mathrm{Se}(\mathrm{VI})$ ) at trace levels in natural lake and river water samples, Rare Metals 30 (5) (2011) 477487. https://doi.org/10.1007/s12598-011-0416-0.

[22] Chen, Y.-H., Zhang, Y.-N., Tiana, F.-S., Determination of selenium via the fluorescence quenching effect of selenium on hemoglobin catalyzed peroxidative reaction, Luminescence 30 (3) (2015) 263268. https://doi.org/10.1002/bio.2723.

[23] Gurkan, R., Akcay, M., Kinetic spectrophotometric determination of trace amounts of selenium based on the catalytic reduction of maxilon blue-SG by sulfide,

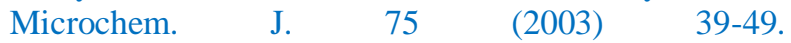
https://doi.org/10.1016/S0026-265X(03)00049-3.

[24] Keyvanfard, M., Kinetic-Spectrophotometric Determination of Trace Amounts of Vanadium (V) Based on its Catalytic Effect on the Oxidation of Victoria Blue B by Potassium Bromate in Micellar Medium, World Appl. Sci. J. 6 (5) (2009) 624-629. https://www.idosi.org/wasj/wasj6(5)/8.pdf.

[25] Temel, N. K., Gürkan, R., A micellar sensitized kinetic method for quantification of low levels of bisphenol A in foodstuffs by spectrophotometry, Anal. Methods 9 (7) (2017) 1190-1200. https://doi.org/10.1039/C6AY03064E.

[26] Martinez-Lozano, C., Perez-Ruiz, T., Tomas, V., Abellan, C., Flow injection spectrophotometric determination of selenium based on the catalyzed reduction of Toluidine Blue in the presence of sulphide ion, Analyst $114 \quad$ (1989) 715-717. https://doi.org/10.1039/AN9891400715.

[27] Gökmen, I. G., Abdelkader, E., Determination of selenium in biological matrices using a kinetic catalytic method, Analyst 119 (4) (1994) 703-708. https://doi.org/10.1039/AN9941900703.

[28] Ensafi, A. A., Dehaghi, G. B., Kineticspectrophotometric determination of trace amounts of selenium with catalytic reduction of gallocyanine by sulfide, Anal. Lett. 28 (2) (1995) 335-347. https://doi.org/10.1080/00032719508000326.

[29] Safavi, A., Afkhami, A., Catalytic spectrophotometric determination of selenium, Anal.
Lett. $28 \quad$ (6) (1995) 1095-1105. https://doi.org/10.1080/00032719508002681.

[30] Safavi, A., Sedghi, H. R., Shams, E., Kinetic spectrophotometric determination of trace amounts of selenium and vanadium, Fresenius J. Anal. Chem. 365 (6) (1999) 504-510 https://doi.org/10.1007/s002160051513.

[31] Chand, V., Prasad, S., Trace determination and chemical speciation of selenium in environmental water samples using catalytic kinetic spectrophotometric method, J. Hazard. Mater. 165 (1-3) (2009) 780-788. https://doi.org/10.1016/j.jhazmat.2008.10.076.

[32] Burstein, S., Reduction of phosphomolybdic acid by compounds possessing conjugated double bonds, Anal. Chem. $25 \quad$ (3) (1953) 422-424. https://doi.org/10.1021/ac60075a012.

[33] Zarzycki, P. K., Bartoszuk, M. A., Radziwon, A. I., Optimization of TLC detection by phosphomolybdic acid staining for robust quantification of cholesterol and bile acids, JPC-J, Planar Chrom-Modern TLC 19 (107) (2006) 52-57. https://doi.org/10.1556/JPC.19.2006.1.9.

[34] Zarzycki, P. K., Bartoszuk, M. A., Improved TLC detection of prostaglandins by post-run derivatization with phosphomolybdic acid, JPC-J. Planar ChromModern TLC $21 \quad$ (5) (2008) 387-390. https://doi.org/10.1556/JPC.21.2008.5.12.

[35] Sims, R. P. A., Formation of heteropoly blue by some reduction procedures used in the microdetermination of phosphorous, Analyst 86 (1961) 584 590. https://doi.org/10.1039/AN9618600584.

[36] Theodore, G. T., Determination of aqueous phosphate by ascorbic acid reduction of phosphomolybdic acid, Anal. Chem. 58 (1) (1986) 223 229. https://doi.org/10.1021/ac00292a054.

[37] Zatar, N. A., Abu-Eid, M. A., Eid, A. F., Spectrophotometric determination of nitrite and nitrate using phosphomolybdenum blue complex, Talanta 50 (4) (1999) 819-826. https://doi.org/10.1016/S00399140(99)00152-6.

[38] Sicilia, D., Rubio, S., Perez-Bendito, D., Kinetic determination of antimony(III) based on its accelerating effect on the reduction of 12-phosphomolybdate by ascorbic acid in a micellar medium, Anal. Chem. 64 (13) (1992) 1490-1495. https://doi.org/10.1021/ac00037a031.

[39] Tosi, E. A., Cazzoli, A. F., Tapiz, L. M., Phosphorous in oil. Production of molybdenum blue 
derivative at ambient temperature using noncarcinogenic reagents, J. Am. Oil Chem. Soc. 75 (1998) 41-44. https://doi.org/10.1007/s11746-998-0007-x.

[40] Nalumansi, I., Mbabazi, J., Ssekaalo, H., Ntale, M., Effect of various reductants on the spectral characteristics of the reduced phosphopolyoxomolybdate anion, and its application to orthophosphate anion quantification in selected Ugandan waters, Int. J. Curr. Trends in Engin. Technol. $1 \quad$ (2) 59-66. http://www.ijctet.org/assets/upload/463IJCTET123.pdf

[41] Shukor, Y., Adam, H., Ithnin, K., Yunus, I., Shamaan, N.A., Syed, M.A., Molybdate reduction to molybdenum blue in microbe proceeds via a phosphomolybdate intermediate, J. Biol. Sci. 7 (8) (2007) $1448-1452$. https://doi.org/10.3923/jbs.2007.1448.1452.

[42] Derun, E. M., Kipcak, A. S., Ozdemir, O.D., Piskin, M. B. Cr, Fe and Se Contents of the Turkish Black and Green Teas and the Effect of Lemon Addition, Int. Scholar. Sci. Res. Innov. 6 (11) (2012) 1018-1021. https://publications.waset.org/7515/pdf. 